University of Nebraska - Lincoln

DigitalCommons@University of Nebraska - Lincoln

$10-21-2002$

\title{
Seasonality of ecosystem respiration and gross primary production as derived from FLUXNET measurements
}

\author{
Eva Falge \\ Pflanzenökologie, Universität Bayreuth, 95440 Bayreuth, Germany \\ Dennis D. Baldocchi \\ University of California - Berkeley, baldocchi@berkeley.edu \\ John Tenhunen \\ Pflanzenökologie, Universität Bayreuth, 95440 Bayreuth, Germany \\ Marc Aubinet \\ Unité de Physique, Faculté des Sciences, Agronomiques de Gembloux, B-50 30 Gembloux, Belgium \\ Peter Bakwin \\ NOAA/OAR, Climate Monitoring and Diagnostics Laboratory, 325 Broadway, Boulder, C0 80303, USA \\ See next page for additional authors \\ Follow this and additional works at: https://digitalcommons.unl.edu/natrespapers \\ Part of the Natural Resources and Conservation Commons
}

Falge, Eva; Baldocchi, Dennis D.; Tenhunen, John; Aubinet, Marc; Bakwin, Peter; Berbigier, Paul; Bernhofer, Christian; Burba, George; Clement, Robert; Davis, Kenneth J.; Elbers, Jan A.; Goldstein, Allen H.; Grelle, Achim; Granier, Andre; Gundmundsson, Jon; Hollinger, David; Kowalski, Andrew S.; Katul, Gabriel; Law, Beverly E.; Malhi, Yadvinder; Meyers, Tilden; Monson, Russell K.; Munger, J. William; Oechel, Walt; Paw U, Kyaw Tha; Pilegaard, Kim; Rannik, Ullar; Rebmann, Corinna; Suyker, Andrew E.; Valentini, Riccardo; Wilson, Kell; and Wofsy, Steve, "Seasonality of ecosystem respiration and gross primary production as derived from FLUXNET measurements" (2002). Papers in Natural Resources. 61.

https://digitalcommons.unl.edu/natrespapers/61

This Article is brought to you for free and open access by the Natural Resources, School of at DigitalCommons@University of Nebraska - Lincoln. It has been accepted for inclusion in Papers in Natural Resources by an authorized administrator of DigitalCommons@University of Nebraska - Lincoln. 


\section{Authors}

Eva Falge, Dennis D. Baldocchi, John Tenhunen, Marc Aubinet, Peter Bakwin, Paul Berbigier, Christian Bernhofer, George Burba, Robert Clement, Kenneth J. Davis, Jan A. Elbers, Allen H. Goldstein, Achim Grelle, Andre Granier, Jon Gundmundsson, David Hollinger, Andrew S. Kowalski, Gabriel Katul, Beverly E. Law, Yadvinder Malhi, Tilden Meyers, Russell K. Monson, J. William Munger, Walt Oechel, Kyaw Tha Paw U, Kim Pilegaard, Ullar Rannik, Corinna Rebmann, Andrew E. Suyker, Riccardo Valentini, Kell Wilson, and Steve Wofsy 


\title{
Seasonality of ecosystem respiration and gross primary production as derived from FLUXNET measurements
}

\author{
Eva Falge ${ }^{\mathrm{a}, *}$, Dennis Baldocchi ${ }^{\mathrm{b}}$, John Tenhunen ${ }^{\mathrm{a}}$, Marc Aubinet ${ }^{\mathrm{c}}$, Peter Bakwin $^{\mathrm{d}}$, \\ Paul Berbigier ${ }^{\mathrm{e}}$, Christian Bernhofer ${ }^{\mathrm{f}}$, George Burba ${ }^{\mathrm{g}}$, Robert Clement ${ }^{\mathrm{h}}$, \\ Kenneth J. Davis $^{i}$, Jan A. Elbers ${ }^{j}$, Allen H. Goldstein ${ }^{b}$, Achim Grelle ${ }^{k}$, \\ André Granier ${ }^{1}$, Jón Guð̊mundsson ${ }^{\mathrm{m}}$, David Hollinger ${ }^{\mathrm{n}}$, Andrew S. Kowalski ${ }^{\mathrm{o}}$, \\ Gabriel Katul $^{\mathrm{p}}$, Beverly E. Law ${ }^{\mathrm{q}}$, Yadvinder Malhi ${ }^{\mathrm{h}}$, Tilden Meyers ${ }^{\mathrm{r}}$, \\ Russell K. Monson ${ }^{\mathrm{s}}$, J. William Munger ${ }^{\mathrm{t}}$, Walt Oechel ${ }^{\mathrm{u}}$, Kyaw Tha Paw Uv, \\ Kim Pilegaard ${ }^{\mathrm{w}}$, Üllar Rannik ${ }^{\mathrm{x}}$, Corinna Rebmann ${ }^{\mathrm{y}}$, Andrew Suyker ${ }^{\mathrm{g}}$, \\ Riccardo Valentini $^{\mathrm{z}}$, Kell Wilson ${ }^{\mathrm{r}}$, Steve Wofsy ${ }^{\mathrm{t}}$ \\ ${ }^{a}$ Pflanzenökologie, Universität Bayreuth, 95440 Bayreuth, Germany \\ b ESPM, University of California at Berkeley, Berkeley, CA 94720, USA \\ ${ }^{\mathrm{c}}$ Unité de Physique, Faculté des Sciences, Agronomiques de Gembloux, B-50 30 Gembloux, Belgium \\ d NOAA/OAR, Climate Monitoring and Diagnostics Laboratory, 325 Broadway, Boulder, CO 80303, USA \\ e INRA, Bioclimatologie, Bordeaux, France \\ ${ }^{f}$ Technische Universität Dresden, IHM Meteorologie, Pienner Str. 9, 01737 Tharandt, Germany \\ ${ }^{g}$ School of Natural Resource Sciences, University of Nebraska-Lincoln, 244 L.W. Chase Hall, P.O. Box 830728, Lincoln, NE 68583-0728, USA \\ ${ }^{\mathrm{h}}$ Institute of Ecology and Resource Management, University of Edinburgh, Edinburgh EH9 3JU, UK \\ ${ }^{\mathrm{i}}$ Department of Meteorology, Pennsylvania State University, University Park, PA 16802, USA \\ ${ }^{\mathrm{j}}$ Alterra, Postbus 47, 6700 AA Wageningen, The Netherlands \\ ${ }^{\mathrm{k}}$ Department of Ecology and Environmental Research, Swedish University of Agricultural Sciences, S-750 07 Uppsala, Sweden \\ ${ }^{1}$ INRA, Unité d'Ecophysiologie Forestière, F-54280 Champenoux, France \\ ${ }^{\mathrm{m}}$ Department of Environmental Research, Agricultural Research Institute, Keldnaholti, IS-112 Reykjavik, Iceland \\ ${ }^{\mathrm{n}}$ USDA Forest Service, 271 Mast Road, Durham, NH 03824, USA \\ ${ }^{\circ}$ Research Group of Plant and Vegetation Ecology, Department of Biology, University of Antwerpen, \\ Universiteitsplein 1, B-2610 Wilrijk, Antwerp, Belgium \\ p School of the Environment, Duke University, Box 90328, Durham, NC 27708-0328, USA \\ ${ }^{\mathrm{q}}$ Richardson Hall, Oregon State University, Corvallis, OR 97331-2209, USA \\ ${ }^{\mathrm{r}}$ NOAA/ATDD, 456 S. Illinois Avenue, Oak Ridge, TN 37831-2456, USA \\ ${ }^{s}$ Department of Environmental, Population, and Organismic Biology, University of Colorado, Campus Box 334, Boulder, CO 80309, USA \\ ${ }^{\mathrm{t}}$ Department of Earth and Planetary Sciences, Harvard University, 20 Oxford St., Cambridge, MA 02138, USA \\ u Department of Biology, San Diego State University, San Diego, CA, USA \\ ${ }^{\vee}$ Atmospheric Science Group, LAWR, UC Davis, 122 Hoagland Hall, Davis, CA 95616, USA \\ ${ }^{w}$ Plant Biology and Biogeochemistry Department, Risoe National Laboratory, P.O. Box 49, DK-4000 Roskilde, Denmark \\ ${ }^{x}$ Department of Physics, University of Helsinki, P.O. Box 9, FIN-00014 Helsinki, Finland \\ ${ }^{y}$ Max-Planck-Institut für Biogeochemie, Tatzendpromenade 1a, 07701 Jena, Germany \\ ${ }^{\mathrm{z}}$ Department of Forest Environment and Resources, University of Tuscia, I-01100 Viterbo, Italy
}

Accepted 3 April 2002

\footnotetext{
${ }^{*}$ Corresponding author. Tel.: +49-921-55-2576; fax: +49-921-55-2564.

E-mail address: falge@uni-bayreuth.de (E. Falge).
} 


\begin{abstract}
Differences in the seasonal pattern of assimilatory and respiratory processes are responsible for divergences in seasonal net carbon exchange among ecosystems. Using FLUXNET data (http://www.eosdis.ornl.gov/FLUXNET) we have analyzed seasonal patterns of gross primary productivity $\left(F_{\mathrm{GPP}}\right)$, and ecosystem respiration $\left(F_{\mathrm{RE}}\right)$ of boreal and temperate, deciduous and coniferous forests, Mediterranean evergreen systems, a rainforest, temperate grasslands, and $\mathrm{C}_{3}$ and $\mathrm{C}_{4}$ crops. Based on generalized seasonal patterns classifications of ecosystems into vegetation functional types can be evaluated for use in global productivity and climate change models. The results of this study contribute to our understanding of respiratory costs of assimilated carbon in various ecosystems.

Seasonal variability of $F_{\mathrm{GPP}}$ and $F_{\mathrm{RE}}$ of the investigated sites increased in the order tropical $<$ Mediterranean $<$ temperate coniferous $<$ temperate deciduous $<$ boreal forests. Together with the boreal forest sites, the managed grasslands and crops show the largest seasonal variability. In the temperate coniferous forests, seasonal patterns of $F_{\mathrm{GPP}}$ and $F_{\mathrm{RE}}$ are in phase, in the temperate deciduous and boreal coniferous forests $F_{\mathrm{RE}}$ was delayed compared to $F_{\mathrm{GPP}}$, resulting in the greatest imbalance between respiratory and assimilatory fluxes early in the growing season.

$F_{\mathrm{GPP}}$ adjusted for the length of the carbon uptake period decreased at the sampling sites across functional types in the order $\mathrm{C}_{4}$ crops, temperate and boreal deciduous forests $\left(7.5-8.3 \mathrm{~g} \mathrm{C} \mathrm{m}^{-2}\right.$ per day) $>$ temperate conifers, $\mathrm{C}_{3}$ grassland and crops $\left(5.7-6.9 \mathrm{~g} \mathrm{C} \mathrm{m}^{-2}\right.$ per day) $>$ boreal conifers $\left(4.6 \mathrm{~g} \mathrm{C} \mathrm{m}^{-2}\right.$ per day). Annual $F_{\mathrm{GPP}}$ and net ecosystem productivity $\left(F_{\mathrm{NEP}}\right)$ decreased across climate zones in the order tropical $>$ temperate $>$ boreal. However, the decrease in $F_{\mathrm{NEP}}$ with latitude was greater than the decrease in $F_{\mathrm{GPP}}$, indicating a larger contribution of respiratory (especially heterotrophic) processes in boreal systems.
\end{abstract}

(C) 2002 Elsevier Science B.V. All rights reserved.

Keywords: Season length; Gross primary production; Ecosystem respiration; FLUXNET; EUROFLUX; AmeriFlux; eddy covariance

\section{Introduction}

Ecosystem $\mathrm{CO}_{2}$ exchange is comprised of fluxes associated with assimilatory and respiratory processes. Timing and amplitude of these components determine the seasonal pattern of net $\mathrm{CO}_{2}$ flux (Randerson et al., 1999; White et al., 1999; Cramer et al., 1999). While at temperate and high latitudes the period for assimilation is usually restricted by temperature and moisture, respiratory processes continue throughout the year. Major factors affecting the seasonal course and amount of ecosystem gross primary production $\left(F_{\mathrm{GPP}}\right)$, are seasonal differences in leaf-area index, physiological capacity, meteorological conditions, and the length of the growing season. Ecosystem respiration $\left(F_{\mathrm{RE}}\right)$ as the sum of heterotrophic respiration $\left(F_{\mathrm{RH}}\right)$, and autotrophic respiration $\left(F_{\mathrm{RA}}\right)$, is typically dominated by disparate factors. The activity of soil microbes contributes to $F_{\mathrm{RH}}$, and is strongly regulated by soil temperature and moisture status (Edwards, 1975; Lloyd and Taylor, 1994; Davidson et al., 1998; Xu and Qi, 2001). While $F_{\mathrm{RA}}$ may be maintained over the course of the year, the partitioning of autotrophic respiration varies seasonally as the relative roles of growth and maintenance respiration change. Periods of microbial activity does not necessarily coincide with those where green plants are photosynthetically active, as microbial activity depends on suitable meteorological conditions as well as on substrate availability and quality. Clearly, it is the interplay between photosynthetic and microbial active seasons, that determines the seasonal pattern, phasing and amplitude of ecosystem energy and material fluxes.

The balance between respiratory and assimilatory processes is likely to be affected as a result of climate change (Houghton et al., 1996). Systematic changes in the length of the growing season (Keeling et al., 1996a; Myneni et al., 1997; Hasenauer et al., 1999; Menzel and Fabian, 1999; Randerson et al., 1999; Keyser et al., 2000; Baldocchi et al., 2001) indicate an extension of the period favorable for assimilation. The influence of climate on respiratory processes is generally more complicated. Soil respiration, for example, is strongly coupled to soil temperature (Raich and Schlesinger, 1992; Lloyd and Taylor, 1994), however, in some ecosystems microbial activity is affected by soil moisture (e.g., Hanson et al., 1993; Fliebach et al., 1994; Law et al., 2000). Soil models typically predict an exponential increase of soil respiration with temperature, but with a secondary limitation by the 
quantity and quality of the substrate for microbial activity (Rastetter et al., 1992). The feedbacks between temperature, moisture availability, and substrate properties seem to control the overall rate of soil respiration (Raich and Tufekciogul, 2000). In addition, temperature increases due to climate change are not evenly distributed over the time of the day with greater increases observed during night than in the day-time (Easterling et al., 1997). Shifts in the relative contribution of assimilation and respiration to total fluxes could affect future ecosystem carbon sequestration potentials, and the stability of stored carbon (Alward et al., 1999). On the other hand, potential shifts in photosynthetic and microbial activities could reduce or reverse the benefits of increased growing season length to carbon sequestration.

At temperate and high latitudes carbon balances of terrestrial ecosystems undergo strong seasonal fluctuations. Growing season length strongly affects annual net ecosystem productivity $F_{\mathrm{NEP}}\left(=F_{\mathrm{GPP}}-F_{\mathrm{RE}}\right)$, (Black et al., 1996, 2000; Goulden et al., 1998; Baldocchi et al., 2001; Meyers, 2001), and ecosystem net primary production, $F_{\mathrm{NPP}}\left(=F_{\mathrm{GPP}}-F_{\mathrm{RA}}\right)$ (Schulze et al., 1999). Model analyses suggest major impacts of growing season length on $F_{\mathrm{NPP}}$ (Field et al., 1998; White et al., 1999; Jackson et al., 2000). Average $F_{\text {NPP }}$, for example, varies among biomes between 0 and $1.2 \mathrm{~kg} \mathrm{C} \mathrm{m}^{-2}$ per year (Bergen and Dobson, 1999; Cramer et al., 1999; Goetz et al., 1999; Jiang et al., 1999; Nemry et al., 1999), but differences in $F_{\mathrm{NPP}}$ are much smaller when adjusted for the length of the growing season. These studies address seasonal fluctuations of the net fluxes, $F_{\mathrm{NEP}}$, or $F_{\mathrm{NPP}}$, but the component fluxes, $F_{\mathrm{GPP}}$ and $F_{\mathrm{RE}}$, often have dissimilar periods of activity. For instance, $F_{\mathrm{GPP}}$ is strongly dependent on light during the growing season when temperature is adequate for growth, whereas $F_{\mathrm{RE}}$ is strongly dependent on temperature and moisture. Over the season light, temperature and moisture are out of phase, and this differs with latitude. Hence these drivers will affect net ecosystem carbon exchange $\left(F_{\mathrm{NEE}}\right)$ differently as they force $F_{\mathrm{GPP}}$ and $F_{\mathrm{RE}}$ differently (Randerson et al., 1999). Consequently, we need to understand primarily the factors that influence the seasonality of the component fluxes, $F_{\mathrm{RE}}$ and $F_{\mathrm{GPP}}$, and govern the seasonal patterns of net fluxes.

Tower-based observing systems based on micrometeorological techniques provide means to directly measure $F_{\mathrm{NEE}}$, which differs from $F_{\mathrm{NEP}}$ by the amount of carbon exported from the system via run-off or harvest. Valentini et al. (2000) used data from a network of tower observations to obtain $F_{\mathrm{RE}}$ and $F_{\mathrm{GPP}}$ by an extrapolation of site-specific exponential relationships between nocturnal fluxes and soil temperature into the day to calculate continuous records of $F_{\mathrm{RE}}$. This approach allows us to investigate seasonal phasing and amplitudes of ecosystem respiration and assimilation. We make use of FLUXNET (http://www.eosdis.ornl.gov/FLUXNET), a data base with ecosystem $\mathrm{CO}_{2}$ flux $\left(F_{\mathrm{NEE}}\right)$ and meteorological data obtained from tower-based systems between years 1992 and 2000. The sites on the European and American continents include deciduous and evergreen forests, grassland and crops, and cover a wide range of climatic zones, from boreal to tropical. The analysis provides valuable insight into the seasonality of respiration and assimilation for sites in a variety of ecotones, and better understanding of the processes that regulate $F_{\mathrm{NEE}}$. This work contributes to our understanding of how well seasonal phasing and amplitudes of respiratory and assimilatory processes are currently represented in carbon cycle and soil-vegetation-atmosphere transfer (SVAT) models.

\section{Methods}

\subsection{The data base and sites}

FLUXNET (http://www.eosdis.ornl.gov/FLUXNET) hosts a data base of continuous measurements of ecosystem carbon and energy exchange, key meteorological variables and ancillary data describing location, vegetation and climate of the sites. The data sets cover multiple years (1992-2000) of flux tower measurements from the AmeriFlux (23 sites) and EUROFLUX (16 sites, Valentini et al., 2000; Valentini, 2002) projects. From these we selected 35 sites (Table 1), where night-time turbulence and hence $F_{\mathrm{RE}}$ could be assessed (details below). Mass and energy fluxes are measured with the eddy covariance technique (for details see, e.g., Aubinet et al., 2000). The data undergo quality assurance, and missing half-hourly averages are filled using standardized methods to provide complete data sets (Falge et al., 2001). 
Table 1

Vegetation type classification of 35 sites from the EUROFLUX and AmeriFlux projects ${ }^{\mathrm{a}}$

\begin{tabular}{|c|c|c|c|}
\hline Functional vegetation type & Site & Abbreviation & State/country \\
\hline Temperate coniferous forests & $\begin{array}{l}\text { Aberfeldy } \\
\text { WeidenBrunnen }^{\mathrm{b}} \\
\text { Tharandt }^{\mathrm{b}} \\
\text { Loobos }^{\mathrm{b}} \\
\text { Brasschaat }^{\mathrm{b}} \\
\text { Wind River }^{\mathrm{c}} \\
\text { Howland }^{\mathrm{c}} \\
\text { Metolius }^{\mathrm{c}} \\
\text { Duke Forest }^{\mathrm{c}}\end{array}$ & $\begin{array}{l}\text { AB } \\
\text { WE } \\
\text { TH } \\
\text { LO } \\
\text { BR } \\
\text { WR } \\
\text { HL } \\
\text { ME } \\
\text { DU }\end{array}$ & $\begin{array}{l}\text { UK } \\
\text { Germany } \\
\text { Germany } \\
\text { The Netherlands } \\
\text { Belgium } \\
\text { WA/USA } \\
\text { ME/USA } \\
\text { OR/USA } \\
\text { NC/USA }\end{array}$ \\
\hline High altitude coniferous forests & Niwot Ridge ${ }^{c}$ & NR & $\mathrm{CO} / \mathrm{USA}$ \\
\hline Boreal coniferous forests & $\begin{array}{l}\text { North Boreas } \\
\text { Flakaliden }^{\mathrm{c}} \\
\text { Norunda }^{\mathrm{b}} \\
\text { Hyytiala }^{\mathrm{b}}\end{array}$ & $\begin{array}{l}\text { NB } \\
\text { FL } \\
\text { NO } \\
\text { HY }\end{array}$ & $\begin{array}{l}\text { Man./Canada } \\
\text { Sweden } \\
\text { Sweden } \\
\text { Finland }\end{array}$ \\
\hline Temperate deciduous forests & $\begin{array}{l}\text { Vielsalm } \\
\text { Soroe }^{\mathrm{b}} \\
\text { Hesse }^{\mathrm{b}} \\
\text { Harvard }^{\mathrm{c}} \\
\text { WalkerBranch }^{\mathrm{c}}\end{array}$ & $\begin{array}{l}\text { VI } \\
\text { SO } \\
\text { HE } \\
\text { HV } \\
\text { WB }\end{array}$ & $\begin{array}{l}\text { Belgium } \\
\text { Denmark } \\
\text { France } \\
\text { MA/USA } \\
\text { TN/USA }\end{array}$ \\
\hline Cold temperate deciduous forests & $\begin{array}{l}\text { Park Falls/WLEF } \\
\text { Willow Creek }^{\mathrm{c}}\end{array}$ & $\begin{array}{l}\text { WL } \\
\text { WC }\end{array}$ & $\begin{array}{l}\text { WI/USA } \\
\text { WI/USA }\end{array}$ \\
\hline Boreal deciduous forests & Gunnarsholt $^{\mathrm{b}}$ & GU & Iceland \\
\hline Maritime/Mediterranean evergreen forests & $\begin{array}{l}\text { Bordeaux }^{\mathrm{b}} \\
\text { Castelporziano }^{\mathrm{b}} \\
\text { Sky Oaks young } \\
\text { Sky Oaks old }^{\mathrm{c}} \\
\text { Blodgett Forest }^{\mathrm{c}}\end{array}$ & $\begin{array}{l}\text { BO } \\
\text { CP } \\
\text { Skyoung } \\
\text { Skold } \\
\text { BL }\end{array}$ & $\begin{array}{l}\text { France } \\
\text { Italy } \\
\text { CA/USA } \\
\text { CA/USA } \\
\text { CA/USA }\end{array}$ \\
\hline Rainforest & Manaus $^{c}$ & MA & Brazil \\
\hline Grasslands & $\begin{array}{l}\text { LittleWashita }^{\mathrm{c}} \\
\text { Shidler }^{\mathrm{c}} \\
\text { Risoe }^{\mathrm{b}}\end{array}$ & $\begin{array}{l}\text { LW } \\
\text { SH } \\
\text { RI }\end{array}$ & $\begin{array}{l}\text { OK/USA } \\
\text { OK/USA } \\
\text { Denmark }\end{array}$ \\
\hline Crops & $\begin{array}{l}\text { Bondville } \\
\text { Bondville }^{c} \\
\text { Ponca }^{c} \\
\text { Soroe }^{\mathrm{b}}\end{array}$ & $\begin{array}{l}\text { Bvcorn } \\
\text { Bvsoybean } \\
\text { PO } \\
\text { Sowheat }\end{array}$ & $\begin{array}{l}\text { IL/USA } \\
\text { IL/USA } \\
\text { OK/USA } \\
\text { Denmark }\end{array}$ \\
\hline
\end{tabular}

\footnotetext{
${ }^{a}$ For more information on these sites see Falge et al. (2002).

${ }^{\mathrm{b}}$ EUROFLUX projects.

${ }^{c}$ AmeriFlux projects.
}

\subsection{The algorithms}

\subsubsection{Estimates of $F_{\mathrm{RE}}$ and $F_{\mathrm{GPP}}$}

Ecosystem respiration, $F_{\mathrm{RE}}$, is measured directly at the towers during night-time periods with strong turbulence (typically indicated by high surface momentum flux, e.g., Goulden et al., 1996), and was extrapolated to other periods by using exponential regressions of measured $F_{\mathrm{RE}}$ with soil temperature. Alternative methods to estimate $F_{\mathrm{RE}}$ for periods when it was not directly measured includes estimates from biogeochemical or SVAT models (e.g., Baldocchi et al., 2000), from chamber measurements extrapolated to the stand scale (Law et al., 1999; Janssen 
et al., 2001; Xu et al., 2001), or estimates derived from the regression of day-time $F_{\mathrm{NEE}}$ against photosynthetically active radiation (PAR) (e.g., Suyker and Verma, 2001). For the exponential regression here an Arrhenius equation (Eq. (1)) in the form reported by Lloyd and Taylor (1994) was used.

$F_{\mathrm{RE}, \text { night }}=F_{\mathrm{RE}, T_{\mathrm{ref}}} \mathrm{e}^{\left(E_{\mathrm{a}} / R\right)\left(\left(1 / T_{\mathrm{ref}}\right)-\left(1 / T_{\mathrm{K}}\right)\right)}$

where $F_{\mathrm{RE}}, T_{\text {ref }}$, is the ecosystem respiration rate at $T_{\text {ref (we used } 283.16 \mathrm{~K} \text { ) and } E_{\mathrm{a}} \text { the activation energy }}$ in $\mathrm{J} \mathrm{mol}^{-1}$ are fitted site-specific parameters, $R$ the gas constant $\left(8.134 \mathrm{~J} \mathrm{~K}^{-1} \mathrm{~mol}^{-1}\right)$, and $T_{\mathrm{K}}$ is the soil temperature in a depth of $5 \mathrm{~cm}$. The parameter $F_{\mathrm{RE} \text {,Tref }}$ was evaluated for gliding 30-day period starting 1 January but $E_{\mathrm{a}}$ was kept constant over the entire year. This might not be valid, as we expect changes in $E_{\mathrm{a}}$ due to changes in soil moisture conditions and the effects of growth and maintenance respiration. Yet, the overall scatter typically found in the relationship between night-time $T_{\mathrm{K}}$ and $F_{\mathrm{RE}}$ determined by eddy covariance (e.g., Goulden et al., 1996) prevented us from analyzing such effects. For more details on the quality of the fits see Appendix A (see Table 4). The derived parameter sets were applied over the entire year to obtain a continuous record of half-hourly data. Values of $F_{\mathrm{GPP}}$ were calculated as the difference between $F_{\mathrm{RE}}$ and $F_{\mathrm{NEE}}$. For daily values of $F_{\mathrm{RE}}$ and $F_{\mathrm{GPP}}$ the half-hourly results were summed. To address errors in our $F_{\mathrm{RE}}$ (and subsequently $F_{\mathrm{GPP}}$ ) estimates, we compared the estimates to values derived from light responses (hyperbolic relationship between $F_{\mathrm{NEE}}$ and light, using Eq. (1) of Suyker and Verma, 2001).

\subsubsection{Maximum diurnal ecosystem respiration and gross primary production}

We used diurnal maximum fluxes, $F_{\mathrm{RE}}$ and $F_{\mathrm{GPP}}$, to assess the seasonal changes in rates of ecosystem respiration and assimilation. We calculated mean diurnal cycles by bin-averaging the 30 min tower flux data for intervals of 15 days (see Falge et al., 2002, Eq. (1)). This time interval was chosen because a variety of ecosystems fluxes show a spectral gap at this period (Baldocchi et al., 2001). Missing data were filled by look-up table methods based on meteorological conditions (temperature and radiation for $F_{\mathrm{GPP}}$, temperature for $F_{\mathrm{RE}}$, see Falge et al., 2001). This type of gap filling was shown to introduce no bias errors (Falge et al., 2001). Bin-averaging reduced sampling errors by $1 / \sqrt{15}$ (Moncrieff et al., 1996), and the procedure resulted in $350(=365-15)$ mean diurnal courses per year. The maximum values of $F_{\mathrm{RE}}$ and $F_{\mathrm{GPP}}$ for each diurnal course were determined. Estimating averages for 30-day period using Eq. (1) reduces random errors of one-point eddy covariance measurements by a factor of $1 / \sqrt{30}$ or 0.183 , resulting in uncertainties of $\pm 3 \%$ for the mean of a 30-day period if the random error is assumed to be $15 \%$. This does not take into account systematic errors potentially observed with eddy covariance at night or on unfavorable terrain. For a more detailed review of uncertainty estimates, see Goulden et al. (1996) or Moncrieff et al. (1996).

\section{Results}

As $F_{\mathrm{GPP}}$ is calculated from the sum of $F_{\mathrm{RE}}$ and $F_{\mathrm{NEP}}$, errors in $F_{\mathrm{RE}}$ affect the magnitude of $F_{\mathrm{GPP}}$ estimates. Therefore we compared our estimates of $F_{\mathrm{RE}}$ to values derived from the light response of $F_{\mathrm{NEP}}$ during the growing season (April to mid September), where a typical hyperbolic relationship between $F_{\text {NEP }}$ and light can be observed. The methods compare well for most sites (Fig. 1 ): a linear regression yields a slope of 0.94 and an intercept of $0.25 \mathrm{~g} \mathrm{C} \mathrm{m}^{-2}$ perday. Excluding fluxes taken at night when evaluating light responses of $F_{\mathrm{NEP}}$, the above linear comparison has a similar slope of 1.00 and intercept of $-0.17 \mathrm{~g} \mathrm{C} \mathrm{m}^{-2}$ per day but more scatter (data not shown). Three boreal sites (Norunda, North Boreas, Gunnarsholt), and two crop sites (Bondville, Soroe-Wheat) were not included in the linear regression. We also excluded the prairie site (Shidler), which yielded a $20 \%$ smaller estimate when $F_{\mathrm{RE}}$ is derived from light responses, a similar result as reported in Suyker and Verma (2001). In particular, it seems the methods do not compare well in boreal and grass or crop ecosystems. This could be due to low leaf-area indices with dead material and/or bare soil intercepting photons in those systems, reducing photosynthetic light use efficiency. Also, these systems (particularly Norunda) are losing lots of carbon from below ground and other carbon pools, and deviations in the estimates of $F_{\mathrm{RE}}$ eventually reveal the relative differences between short term autotrophic carbon loss versus longer term heterotrophic carbon loss.

Seasonal pattern of maximum and mean diurnal $F_{\mathrm{GPP}}$ and $F_{\mathrm{RE}}$ are shown for four sites in Fig. 2. 


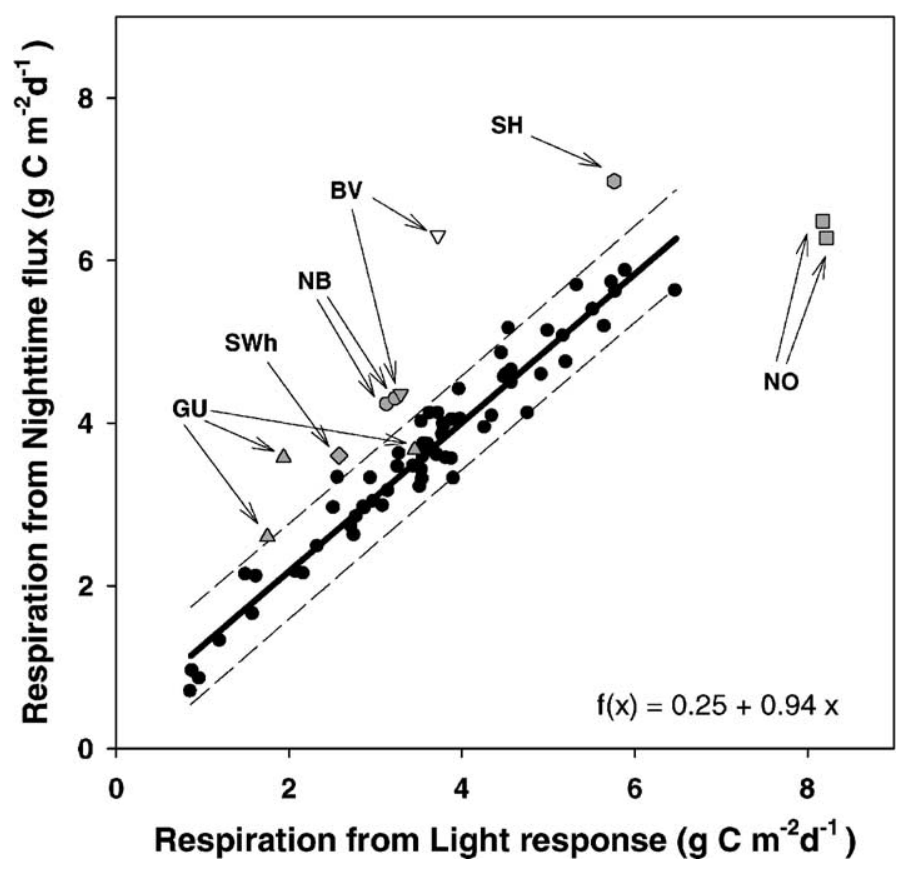

Fig. 1. Ecosystem respiration $\left(F_{\mathrm{RE}}\right)$, calculated from light response relationships (Eq. (1) in Suyker and Verma (2001)) compared to the values derived from exponential regressions between soil temperature and night-time fluxes under turbulent conditions (Eq. (1)). Data represent average daily sums for all days of the growing season where both methods could be applied. Three boreal sites (NO: Norunda; NB: North Boreas; GU: Gunnarsholt), two crop sites (BV: Bondville; SWh: Soroe-Wheat) and the prairie site (SH: Shidler) are not included in the linear regression.

Assimilation is active year-round in the temperate coniferous and the evergreen broad-leaf forest, and shows a very confined season in the deciduous and the boreal forest. With the exemption of the boreal coniferous forest-we find correspondence between the amount of assimilation and respiration, high respiration at high assimilation and low respiration at low assimilation rates. The seasonal course of mean $F_{\mathrm{GPP}}$ shows similar patterns, however the differences between mean $F_{\mathrm{GPP}}$ and $F_{\mathrm{RE}}$ are smaller than for diurnal maximum fluxes. Mean $F_{\mathrm{GPP}}$ and $F_{\mathrm{RE}}$ are mostly out of phase for the boreal conifers, but the temperate and Mediterranean systems show again the compensatory behavior of $F_{\mathrm{GPP}}$ and $F_{\mathrm{RE}}$.

Fig. 3 shows maximum $F_{\mathrm{GPP}}$ for the temperate and boreal deciduous and coniferous forests. $F_{\mathrm{GPP}}$ could not be calculated for all sites due to incomplete seasonal $F_{\mathrm{RE}}$. Site specific data were smoothed by applying a 10-day moving average, and normalized to the maximum observed value during the year. Absolute maximum and minimum values and the corresponding day of the year are given in Table 2. We averaged the data for each site for all available years to reduce the sensitivity of the results to occasional large gaps in the data and to depict biome specific patterns rather than inter-annual variability. Seasonal courses of maximum $F_{\mathrm{GPP}}$ of the temperate and boreal forest sites show the pattern we found for net uptake (see Falge et al., 2002), temperate conifers with the longest, boreal deciduous with the shortest, and temperate deciduous and boreal coniferous forests with intermediate and indeed very similar assimilation periods. The temperate coniferous forests and Vielsalm (VI), a mixed forest, show assimilation potential even in winter. The low assimilation rates at Brasschaat (BR) in April and May are probably due to anthropogenic influences $\left(\mathrm{CO}_{2}\right.$ sources from residential areas). The assimilation potential of the high altitude coniferous forest site (Niwot Ridge, $\mathrm{NW}$ ) is similar to the temperate deciduous forest sites, clearly pointing to a delayed phenology for conifers at high elevations. 

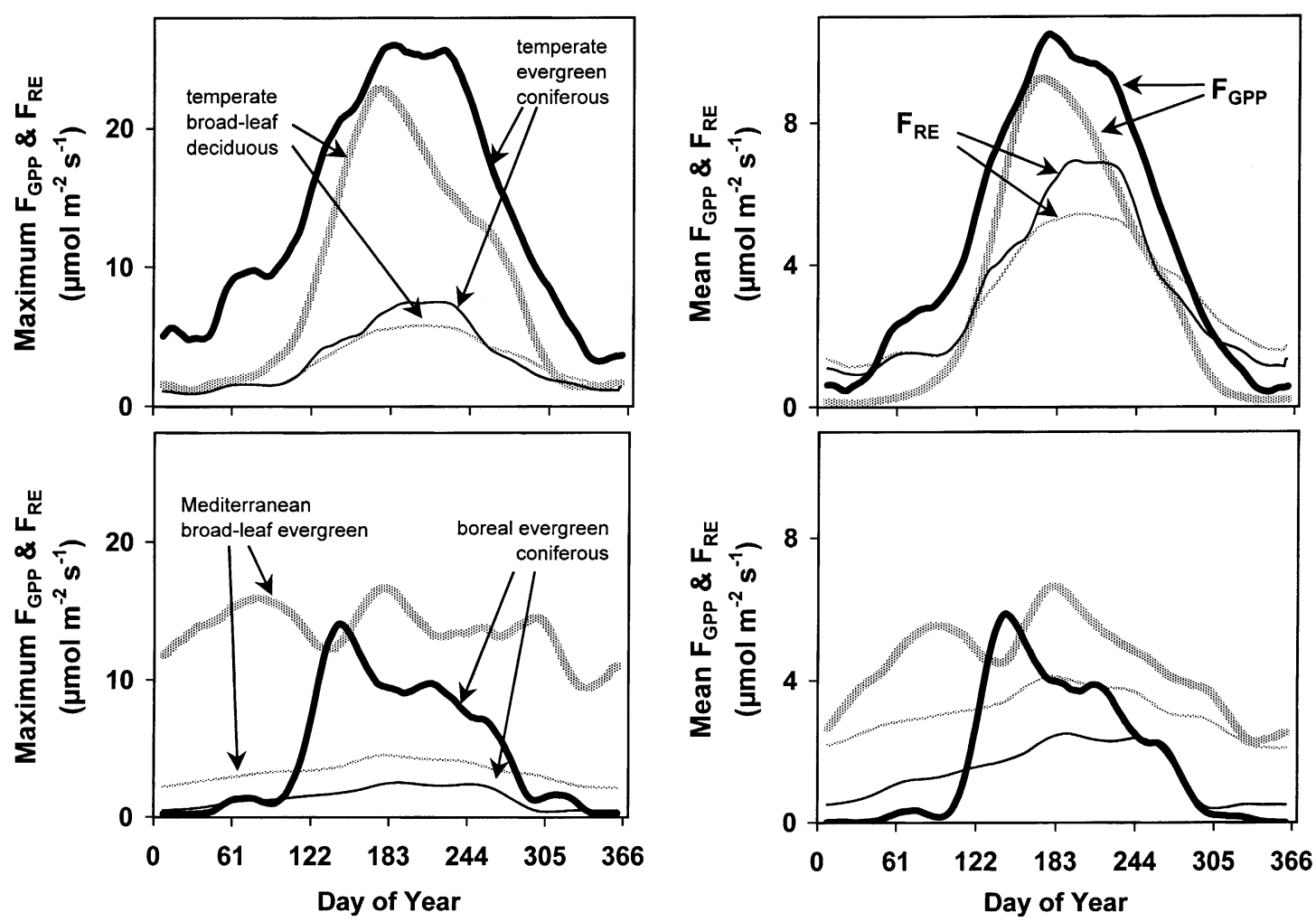

Fig. 2. Seasonal development of maximum mean diurnal ecosystem gross primary production $\left(F_{\mathrm{GPP}}\right)$, and maximum diurnal ecosystem respiration $\left(F_{\mathrm{RE}}\right)$, from 15-day bin-averaged data. Temperate forest sites are in the upper panel (Tharandt and Soroe), and Mediterranean and boreal are in the lower panel (Castelporziano and Flakaliden).

The results for the seasonal trends of maximum $F_{\mathrm{RE}}$ are shown in Fig. 4. In general, they resemble the patterns we described for maximum night-time carbon release in Falge et al. (2002). However, there seems to be a more gradual transition between the patterns of the temperate conifers, temperate deciduous, and the boreal conifers, as we analyze $F_{\mathrm{RE}}$ during the entire day, i.e., maximum values are likely to occur during day-time when temperatures are higher. In general, the seasonal pattern in $F_{\mathrm{RE}}$ reveals a large influence of climate (temperate versus boreal), whereas the life-form (deciduous or coniferous) seems to be less relevant for the seasonality of respiratory processes.

Figs. 5 and 6 summarize seasonal patterns of $F_{\mathrm{GPP}}$ and $F_{\mathrm{RE}}$ for the sites of the remaining functional types, grassland, crops, maritime/Mediterranean ecosystems, and a rainforest. Maximum $F_{\mathrm{GPP}}$ of the evergreen maritime and Mediterranean forests reflects their year-round assimilatory activity (Fig. 5), and maximum $F_{\mathrm{RE}}$ never drops below $25 \%$ of the maximum observed value during the season. However, drought periods are likely to affect $F_{\mathrm{RE}}$ during late spring (CP), or summer (BL, BO). For the temperate grassland sites the phasing of maximum $F_{\mathrm{RE}}$ (Fig. 6) corresponds well with the patterns observed in temperate deciduous forests, however the amplitudes differ: maximum $F_{\mathrm{RE}}$ in the forests (Fig. 4) does not decline to almost 0 in winter, as it is found for the grasslands. Crop sites often develop a second maximum in $F_{\mathrm{GPP}}$ after the harvest due to inter-crops or weeds, and several maximums in $F_{\mathrm{RE}}$ evidently following management practices (Fig. 6).

Summarizing Figs. 3-6, the seasonal patterns observed in Falge et al. (2002) are reflected in the results for $F_{\mathrm{GPP}}$ and $F_{\mathrm{RE}}$ and grouped for the sites in the above functional types. Temperate deciduous and 

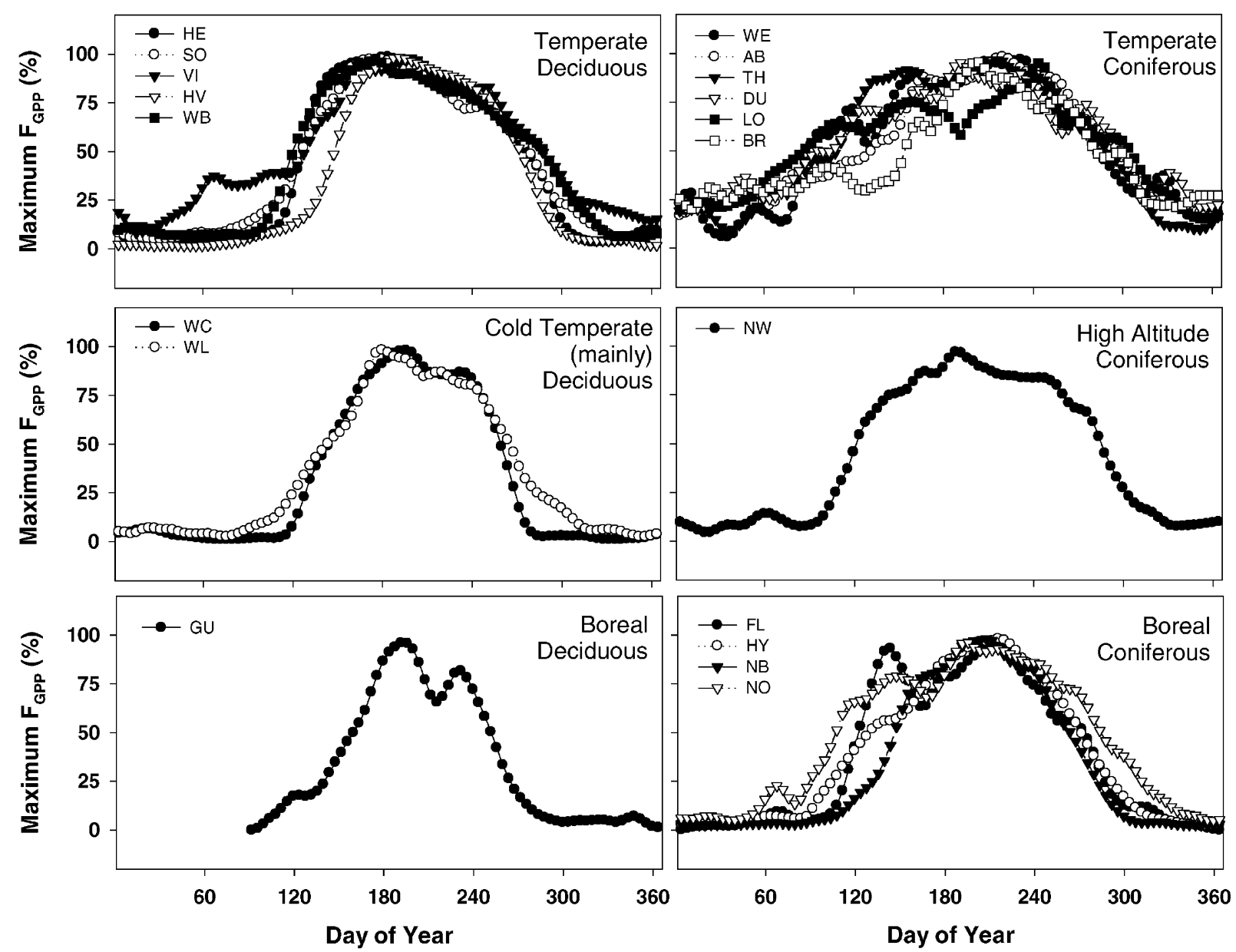

Fig. 3. Seasonal development of maximum diurnal $F_{\mathrm{GPP}}$, for selected sites from Table 1, temperate, cold temperate, and boreal deciduous forests (left panels), and temperate, high altitude, and boreal coniferous forests (right panels). Data are normalized such that the maximum observed value equals $100 \%$. Absolute maximum values are given in Table 2.

boreal coniferous forest sites comprise one class in terms of the seasonal phase and amplitude of $F_{\mathrm{GPP}}$, whereas temperate coniferous sites show a prolonged carbon uptake period together with smaller amplitude. In contrast, the seasonal course of $F_{\mathrm{RE}}$ of the temperate deciduous forest sites matches the pattern found for the temperate conifers, whereas the phasing of $F_{\mathrm{RE}}$ of boreal conifers is shorter and the amplitude larger. Fig. 7 shows the difference between seasonal maximum (set to $100 \%$ ) and minimum $F_{\mathrm{GPP}}$ (values of sampling sites averaged within vegetation functional types). Minimum $F_{\mathrm{GPP}}$ amounts to $75 \%$ of the maximum in the tropical system, $30 \%$ in the maritime/
Mediterranean evergreen systems, $12 \%$ in the temperate coniferous systems, and $0-4 \%$ in the other systems as boreal forest sites, temperate deciduous sites, grasslands and crops. Similarly, minimum seasonal rates of $F_{\mathrm{RE}}$ amounts to $95 \%$ of maximum $F_{\mathrm{RE}}$ in the tropical, $35 \%$ in the maritime/Mediterranean, $14-17 \%$ in the temperate forest sites (deciduous and coniferous), $9 \%$ in the boreal coniferous forests, and $4-6 \%$ in the boreal deciduous forest, grassland and crop sites.

In Falge et al. (2001) we used the ratio between $F_{\mathrm{GPP}}$ and $F_{\mathrm{RE}}\left(z=F_{\mathrm{GPP}} / F_{\mathrm{RE}}\right)$ to evaluate the relative contribution of carbon exchange processes to the 
Table 2

Seasonal maximum and minimum of $F_{\mathrm{GPP}}$ and $F_{\mathrm{RE}}$, together with the day of the year, where maximum and minimum rates occur, for 29 sites from the EUROFLUX and AmeriFlux projects ${ }^{\mathrm{a}}$

\begin{tabular}{|c|c|c|c|c|}
\hline \multirow[t]{2}{*}{ Site } & \multicolumn{2}{|l|}{$F_{\mathrm{GPP}}$} & \multicolumn{2}{|l|}{$F_{\mathrm{RE}}$} \\
\hline & $\begin{array}{l}\text { Seasonal maximum } \\
\left(\mu \mathrm{mol} \mathrm{CO} \mathrm{m}^{-2} \mathrm{~s}^{-1}\right)\end{array}$ & $\begin{array}{l}\text { Seasonal minimum } \\
\left(\mu \mathrm{mol} \mathrm{CO} \mathrm{m}^{-2} \mathrm{~s}^{-1}\right)\end{array}$ & $\begin{array}{l}\text { Seasonal maximum } \\
\left(\mu \mathrm{mol} \mathrm{CO} \mathrm{m}_{2}^{-2} \mathrm{~s}^{-1}\right)\end{array}$ & $\begin{array}{l}\text { Seasonal minimum } \\
\left(\mu \mathrm{mol} \mathrm{CO} \mathrm{m}^{-2} \mathrm{~s}^{-1}\right)\end{array}$ \\
\hline \multicolumn{5}{|c|}{ Temperate coniferous forests } \\
\hline Aberfeldy ${ }^{\mathrm{b}}$ & $16.0(216)$ & $2.5(1)$ & $5.3(225)$ & $0.7(3)$ \\
\hline WeidenBrunnen $^{\mathrm{b}}$ & $18.3(232)$ & $0.7(36)$ & $7.3(230)$ & $1.4(37)$ \\
\hline Tharandt $^{\mathrm{b}}$ & $25.3(216)$ & $2.0(34)$ & $6.9(215)$ & $1.0(35)$ \\
\hline Loobos $^{\mathrm{b}}$ & $24.0(246)$ & $3.5(351)$ & $5.3(177)$ & $1.0(7)$ \\
\hline Brasschaat $^{\mathrm{b}}$ & $20.2(202)$ & $3.4(12)$ & $16(172)$ & $2.1(72)$ \\
\hline Duke Forest $\mathrm{t}^{\mathrm{c}}$ & $24.5(191)$ & $4.6(8)$ & $3.6(206)$ & $1.0(65)$ \\
\hline \multicolumn{5}{|c|}{ High altitude coniferous forests } \\
\hline Niwot Ridge ${ }^{c}$ & $15.1(186)$ & $0.5(23)$ & $6.3(185)$ & $1.0(353)$ \\
\hline \multicolumn{5}{|c|}{ Boreal coniferous forests } \\
\hline North Boreas ${ }^{c}$ & $18.1(210)$ & $0.4(352)$ & $12.8(211)$ & $0.3(28)$ \\
\hline Flakaliden $^{\mathrm{b}}$ & $13.2(219)$ & $0.0(6)$ & $4.1(212)$ & $0.5(12)$ \\
\hline Norunda ${ }^{b}$ & $30.4(191)$ & $1.4(7)$ & $8.6(187)$ & $1.2(41)$ \\
\hline Hyytiala $^{\mathrm{b}}$ & $13.1(219)$ & $0.2(351)$ & $4.0(213)$ & $0.3(43)$ \\
\hline \multicolumn{5}{|c|}{ Temperate deciduous forests } \\
\hline Vielsalm ${ }^{\mathrm{b}}$ & $21.5(196)$ & $1.6(7)$ & $21.5(196)$ & $1.6(7)$ \\
\hline Soroe $^{\mathrm{b}}$ & $25.3(175)$ & $1.1(27)$ & $6.8(208)$ & $1.2(34)$ \\
\hline Hesse $^{\mathrm{b}}$ & $24.8(184)$ & $0.6(14)$ & $7.4(223)$ & $0.8(35)$ \\
\hline Harvard $^{c}$ & $25.0(190)$ & $0.4(49)$ & $4.7(191)$ & $1.0(37)$ \\
\hline Walker Branch $^{\mathrm{c}}$ & 29.9 (176) & $1.8(332)$ & $3.9(202)$ & $0.4(33)$ \\
\hline \multicolumn{5}{|c|}{ Cold temperate deciduous forests } \\
\hline Park Falls/WLEF ${ }^{c}$ & $19.6(178)$ & $0.4(74)$ & $7.9(200)$ & $0.3(363)$ \\
\hline Willow Creek ${ }^{\mathrm{c}}$ & $28.3(190)$ & $0.2(72)$ & $5.7(190)$ & $0.5(22)$ \\
\hline \multicolumn{5}{|c|}{ Boreal deciduous forests } \\
\hline Gunnarsholt ${ }^{\mathrm{b}}$ & $23.0(192)$ & $0.2(1)$ & $13.6(183)$ & $0.1(3)$ \\
\hline \multicolumn{5}{|c|}{ Maritime/Mediterranean evergreen forests } \\
\hline Bordeaux ${ }^{\mathrm{b}}$ & $23.8(159)$ & $7.6(339)$ & $7.4(177)$ & $1.8(29)$ \\
\hline Castelporziano $^{\mathrm{b}}$ & $17.5(178)$ & $8.4(338)$ & $4.6(172)$ & $2.1(4)$ \\
\hline Blodgett Forest ${ }^{\mathrm{c}}$ & $23.8(159)$ & $7.6(339)$ & $3.3(343)$ & $0.9(257)$ \\
\hline \multicolumn{5}{|l|}{ Rainforest } \\
\hline Manaus $^{c}$ & $29.5(4)$ & $22.3(189)$ & $7.2(267)$ & $6.9(362)$ \\
\hline \multicolumn{5}{|l|}{ Grasslands } \\
\hline LittleWashita $^{c}$ & $14.4(176)$ & $0.7(356)$ & $6.6(181)$ & $0.4(362)$ \\
\hline Shidler ${ }^{c}$ & $39.2(182)$ & $0.1(24)$ & $15.0(176)$ & $0.3(14)$ \\
\hline \multicolumn{5}{|l|}{ Crops } \\
\hline Bondville ${ }^{\mathrm{c}} \mathrm{C} 4$ & 60.5 (199) & 0.3 (294) & $15.8(180)$ & $0.1(362)$ \\
\hline Bondville $^{\mathrm{c}} \mathrm{C} 3$ & 27.3 (196) & $0.3(73)$ & 8.7 (182) & $0.0(11)$ \\
\hline Ponca $^{c}$ & $33.5(124)$ & $1.7(226)$ & $6.0(210)$ & $1.4(22)$ \\
\hline Soroe $^{\mathrm{b}}$ & 31.7 (187) & $0.2(25)$ & $10.8(145)$ & $0.0(7)$ \\
\hline
\end{tabular}

${ }^{\text {a }}$ Data are averaged for all available years. Values of $F_{\mathrm{GPP} \text {, max }}$ and $F_{\mathrm{RE} \text {,max }}$ are derived as maximum values from a time series of $F_{\mathrm{GPP}}$ and $F_{\mathrm{RE}}$ using a 15-day running mean filter for each half-hour of the day. Values in parenthesis indicate the day of the year.

${ }^{\mathrm{b}}$ EUROFLUX projects.

${ }^{\mathrm{c}}$ AmeriFlux projects. 

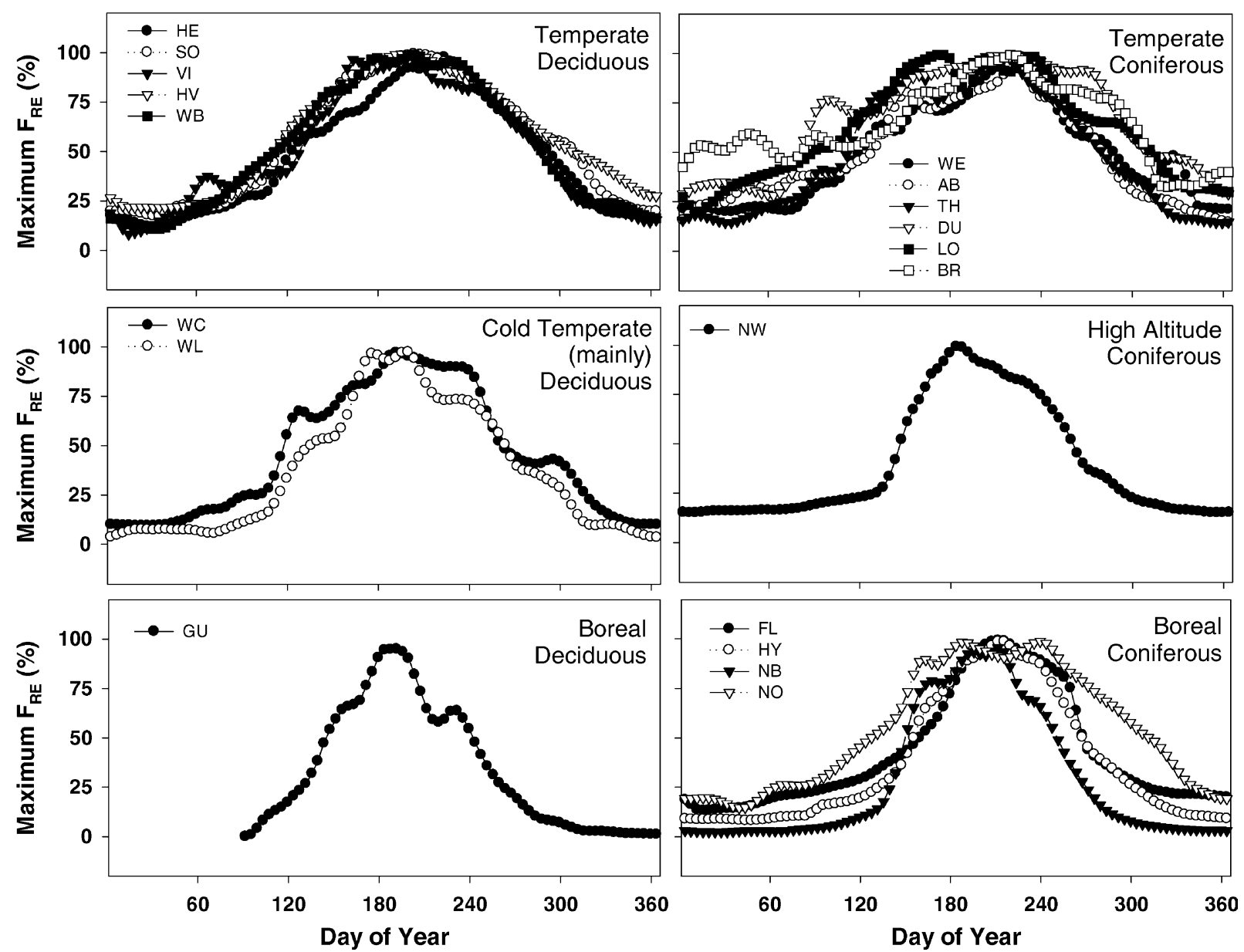

Fig. 4. As in Fig. 3, but for seasonal development of maximum diurnal $F_{\mathrm{RE}}$, for selected sites from Table 1.

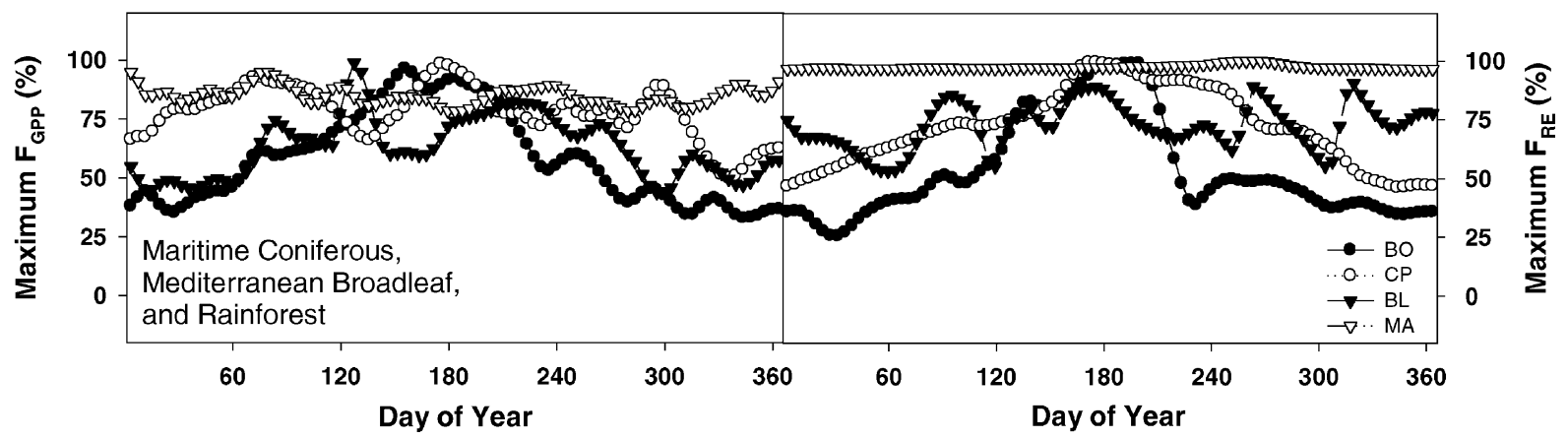

Fig. 5. Seasonal development of maximum diurnal $F_{\mathrm{GPP}}$ (left panel), and maximum mean diurnal $F_{\mathrm{RE}}$ (right panel), for maritime and Mediterranean evergreen forests from Table 1. 


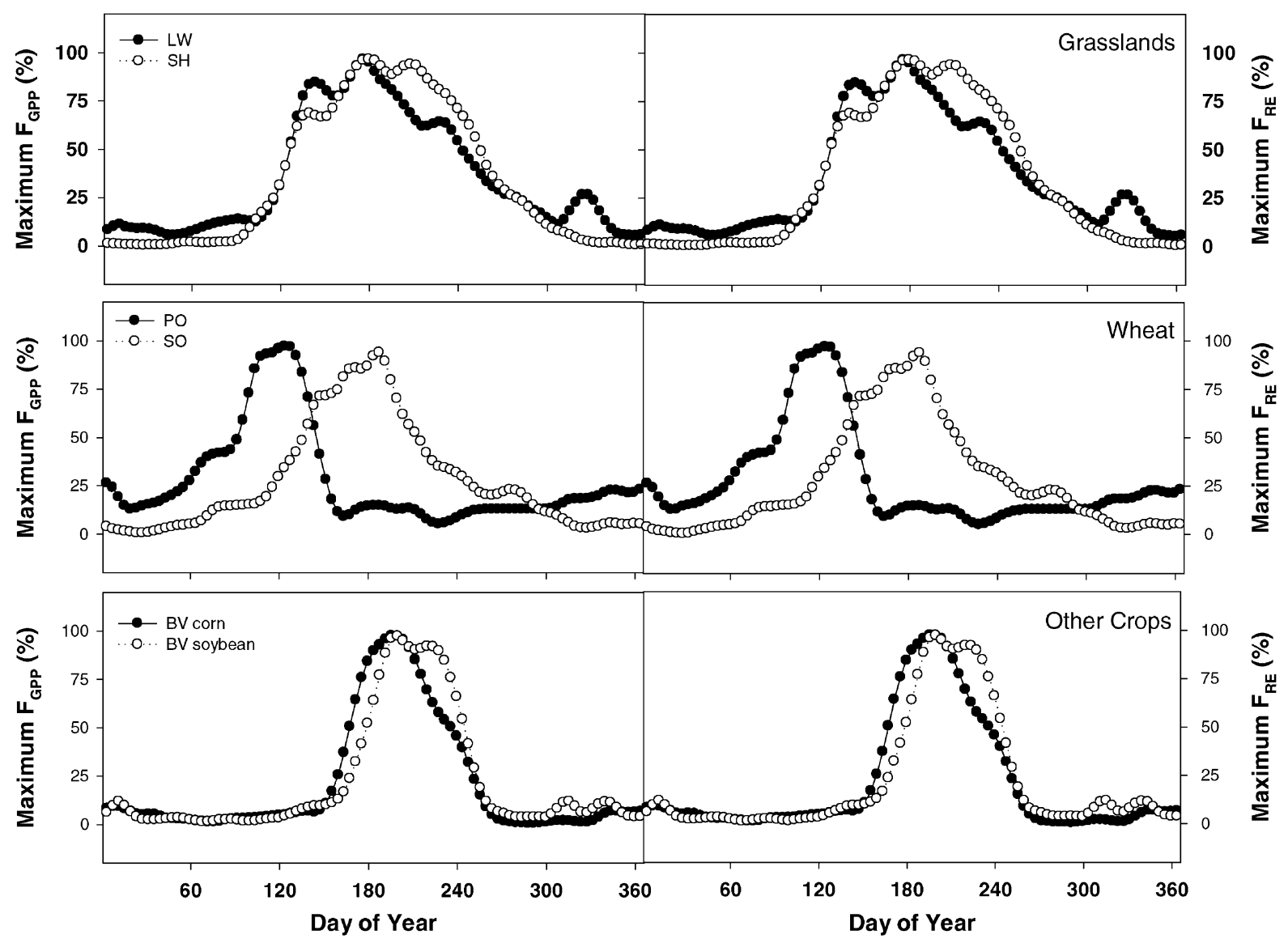

Fig. 6. Seasonal development of maximum diurnal $F_{\mathrm{GPP}}$ (left panel), and maximum diurnal $F_{\mathrm{RE}}$ (right panel), for grassland and crop ecosystems (Table 1).

total annual exchange. This analysis illustrates what fraction of assimilation is consumed by the plant or supports the activities of heterotrophs in the soil. Values of $z$ below 1 occur when the system becomes a source of $\mathrm{CO}_{2}$, while $z=1$ on an annual or decadal basis indicates a system that is in carbon balance $\left(F_{\mathrm{NEE}}=0\right)$. When $F_{\mathrm{GPP}}$ exceeds $F_{\mathrm{RE}}(z>1)$ the system is storing carbon, usually observed in young "growing" stages. When $F_{\mathrm{GPP}}$ substantially exceeds $F_{\mathrm{RE}}$ the system has potential to deprive of free nutrients by accumulating both carbon and available nutrients in (dead) biomass. Considering the close link between soil organic matter decomposition and nutrient cycling, systems with low $F_{\mathrm{RH}}$ will likely show negative feedbacks to growth and $F_{\mathrm{GPP}}$ or become susceptible to disturbance (e.g., Schulze et al., 1999;
Walker et al., 1999; Amiro, 2001). We calculated values of $z$ from monthly sums of $F_{\mathrm{GPP}}$ and $F_{\mathrm{RE}}$ over the course of the year averaged for all available years for each site (Fig. 8). The length of the period during which $z$ was greater than 1 is a measure of the length of the carbon uptake period (in days, $S_{\mathrm{GPP} / \mathrm{RE}}$, see Table 3). Carbon uptake periods were longest in the evergreen systems such as Mediterranean and temperate coniferous forests, shorter in the boreal and temperate deciduous forests and native grasslands, and shortest in the crop systems (not shown) and drought stressed rangeland (LW). Values of $z=2$ (dotted lines in Fig. 8) correspond to $F_{\mathrm{NEP}}=F_{\mathrm{RE}}$, indicating low overall contribution of $F_{\mathrm{RH}}$, suggesting that autotrophic processes mainly govern ecosystem carbon fluxes, as was observed for the crops, the boreal conif- 


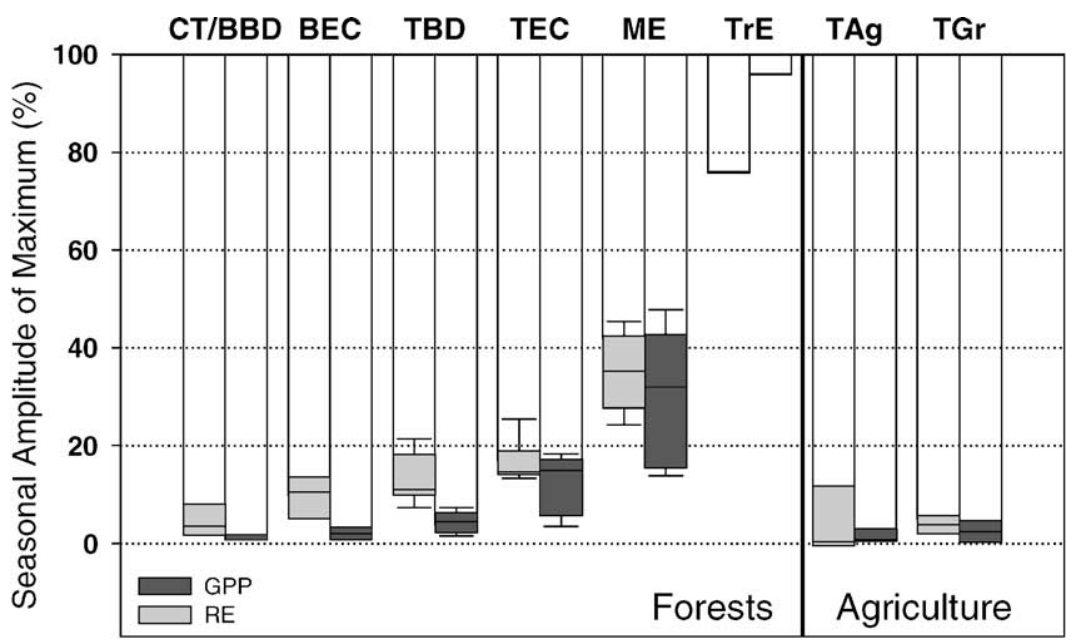

Fig. 7. Seasonal amplitudes of maximum ecosystem gross primary production, $F_{\mathrm{GPP}}$ and maximum ecosystem respiration, $F_{\mathrm{RE}}$, grouped by functional type (CT/BBD: cold temperate broad-leaf deciduous; BEC: boreal evergreen conifers; TBD: temperate broad-leaf deciduous; TEC: temperate evergreen conifers; ME: maritime/Mediterranean evergreen forests; TrE: rainforest; TAg: temperate crops; TGr: temperate grasslands). Data are derived by calculating the ratio between minimum and maximum values reported in Table 2 in percentage, and averaged for each functional type. Box charts are used to emphasize total range, and median.

erous sites in spring and for some temperate deciduous and coniferous forests over several months. In the boreal coniferous systems (Fig. 8a), the large $z$-values in spring reflect physiological activity of the leaves while heterotrophic processes are still slow due to low soil temperatures (Goulden et al., 1998). Low values of $z$, reflecting low rates of photosynthesis, are found in drought stressed ecosystems (LW and BL, Fig. 8b).

\section{Discussion}

In this study we presented phasing and amplitude of ecosystem gross primary production $\left(F_{\mathrm{GPP}}\right)$, and ecosystem respiration $\left(F_{\mathrm{RE}}\right)$ over the course of the year. Data were obtained from eddy covariance tower networks from sites of a variety of functional vegetation types of the Northern Hemisphere, and a tropical rainforest site. We derived seasonal patterns of photosynthetic and respiratory activity, and investigated ecosystem differences in the ratio of organic carbon consumed $\left(F_{\mathrm{RE}}\right)$ and produced $\left(F_{\mathrm{GPP}}\right)$ within the system.

Identification of functional types allows treating groups of vegetation units or species as single entities according to their specific interaction with the envi- ronment. The usefulness of this concept depends on the attributes selected for the classification. From a functional perspective, ecosystems could be grouped by their mass and energy exchange or productivity and respiration rates. Applying a more morphologic view, global models of climate change and productivity employ classification schemes by biome or vegetation type, e.g., evergreen needle-leaf forest, deciduous broad-leaf forest (Warnant et al., 1994; Field et al., 1995; Sellers et al., 1996a,b; Kohlmaier et al., 1997). We analyzed seasonal pattern of $F_{\mathrm{GPP}}$ and $F_{\mathrm{RE}}$ to test the potential to generalize functional characteristics within currently applied classification schemes.

Standard attributes in classification schemes of global models are life-forms (e.g., deciduous or coniferous) and climate (e.g., temperate, boreal). Remarkable parallels were found in seasonal pattern of net ecosystem fluxes $\left(F_{\mathrm{NEP}}\right)$ within and between groups defined by life-form and climate zone (Falge et al., 2002). In general, the seasonal patterns for $F_{\mathrm{GPP}}$ and $F_{\mathrm{RE}}$ from the sampling sites reflect the results observed for $F_{\mathrm{NEP}}$. The seasonal patterns of $F_{\mathrm{RE}}$ of the temperate deciduous and coniferous forests are similar in length to the active period, while the active season for $F_{\mathrm{RE}}$ in the boreal conifers is shorter. In terms of $F_{\mathrm{GPP}}$, in contrary, the temperate deciduous and boreal 
coniferous forest sites are similar, whereas the temperate conifers show a longer active season. The seasonal amplitude of maximum rates of $F_{\mathrm{GPP}}$ and $F_{\mathrm{RE}}$ at the investigated sites increases in the order tropical < maritime/Mediterranean $<$ temperate coniferous $<$ temperate deciduous $<$ boreal evergreen forests $<$ cold temperate and boreal deciduous forests. Again, the temperate and boreal coniferous forests fall in two different classes. Thus, climate has a large impact on the seasonal pattern in $F_{\mathrm{RE}}$ while life-form dictates the seasonality of assimilatory processes.
We assessed ecosystem carbon balances by analyzing the ratio between $F_{\mathrm{GPP}}$ and $F_{\mathrm{RE}}\left(z=F_{\mathrm{GPP}} / F_{\mathrm{RE}}\right.$, Falge et al., 2001). When $z>1$ on an annual or decadal basis the system is storing carbon, when $z=1$ the system is in carbon balance, and $F_{\mathrm{RH}}$ equals $F_{\mathrm{NPP}}$. Typically, the ratio $F_{\mathrm{GPP}} / F_{\mathrm{RE}}$ was between 1 and 2 during the growing season and below 1 during the dormant period, showing the use of stored carbon during this phase. Sites with prolonged periods of values of $2\left(F_{\mathrm{NEP}}=F_{\mathrm{RE}}\right)$ and higher could indicate problems during application of the eddy covariance method, as $F_{\mathrm{GPP}} / F_{\mathrm{RE}}$ will likely be overestimated
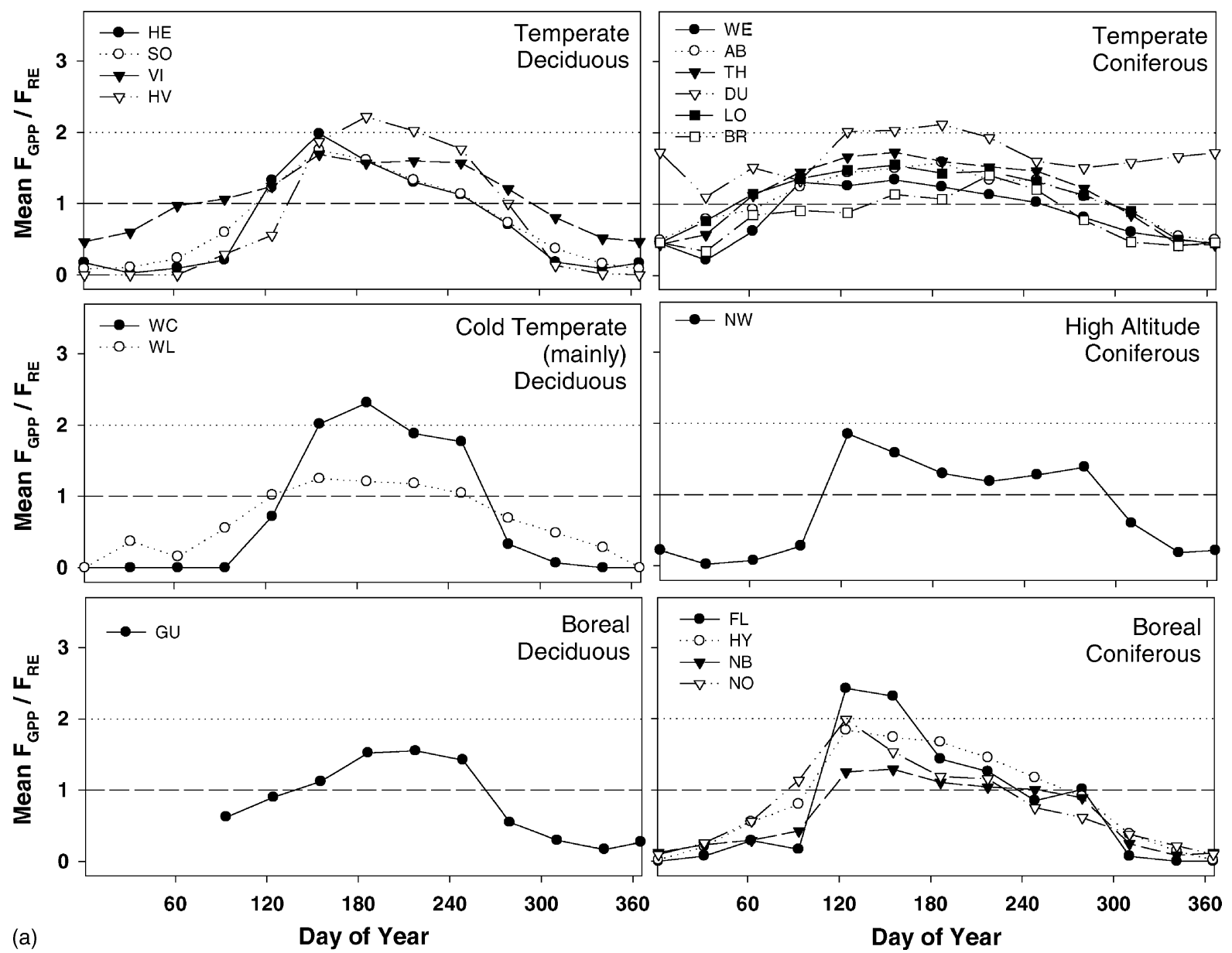

Fig. 8. Seasonal development of the ratio between $F_{\mathrm{GPP}}$ and $F_{\mathrm{RE}}$ for selected sites from Table 1. (a) Left panels: temperate, cold temperate, and boreal deciduous forests, right panels: temperate, high altitude, and boreal coniferous forests; (b) Maritime coniferous, Mediterranean Broadleaf, rainforest and grasslands. The $z$-value of 1 (dashed lines) indicates that $F_{\mathrm{NEE}}$ equals 0 . The $z$-value of 2 (dotted lines) corresponds to $F_{\mathrm{NEE}}$ equals $F_{\mathrm{RE}}$, indicating low overall contribution of $F_{\mathrm{RH}}$. 


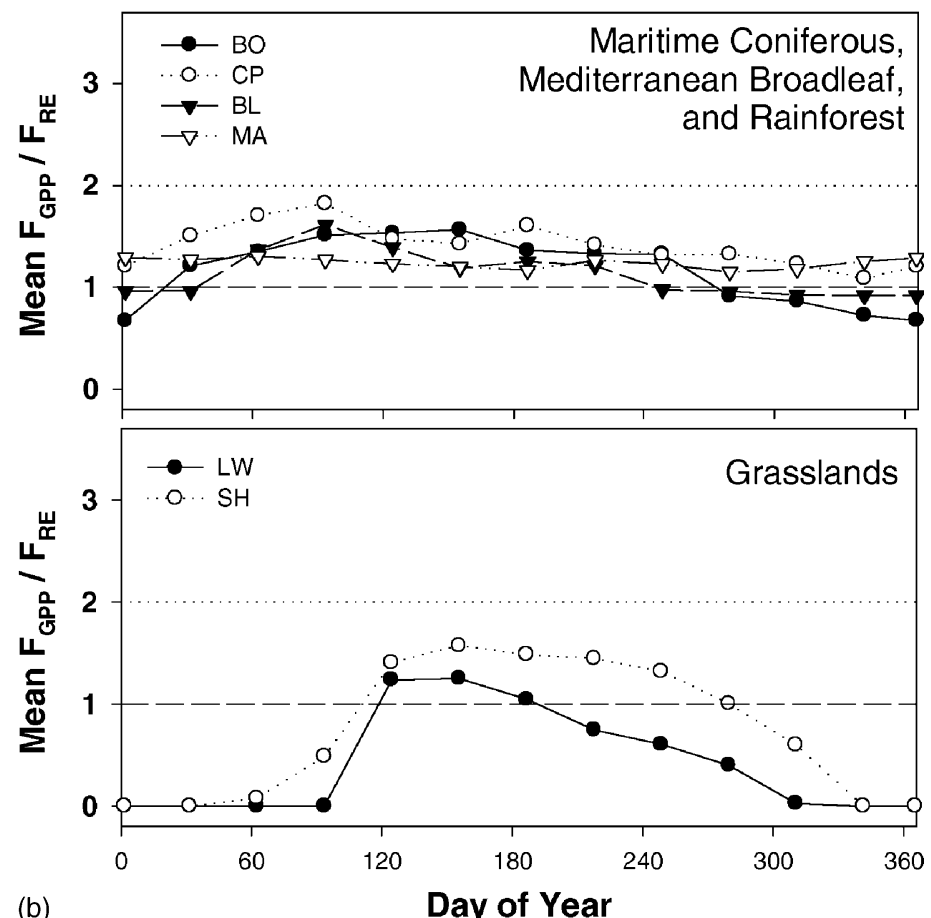

Fig. 8. (Continued).

Table 3

Annual sum of $F_{\mathrm{GPP}}$ and $F_{\mathrm{NEP}}$ estimates of the length of the carbon uptake period, and values of $F_{\mathrm{GPP}}$ and $F_{\mathrm{NEP}}$ adjusted for season length $\left(F_{\mathrm{GPP}}^{\mathrm{d}}\right.$ and $\left.F_{\mathrm{NEP}}^{\mathrm{d}}\right)$ for 35 sites from the EUROFLUX and AmeriFlux projects ${ }^{\mathrm{a}}$

\begin{tabular}{|c|c|c|c|c|c|c|}
\hline Site & $\begin{array}{l}F_{\mathrm{GPP}}\left(\mathrm{g} \mathrm{C} \mathrm{m}^{-2}\right. \\
\text { per year })\end{array}$ & $\begin{array}{l}F_{\mathrm{NEP}}\left(\mathrm{g} \mathrm{C} \mathrm{m}^{-2}\right. \\
\text { per year })\end{array}$ & $\begin{array}{l}S_{\mathrm{GPP} / \mathrm{RE}} \\
\text { (days) }\end{array}$ & $\begin{array}{l}S_{\mathrm{NEP}} \\
\text { (days) }\end{array}$ & $\begin{array}{l}F_{\mathrm{GPP}}^{\mathrm{d}}\left(\mathrm{g} \mathrm{C} \mathrm{m}^{-2}\right. \\
\text { per day })\end{array}$ & $\begin{array}{l}F_{\mathrm{NEP}}^{\mathrm{d}}\left(\mathrm{g} \mathrm{C} \mathrm{m}^{-2}\right. \\
\text { per day) }\end{array}$ \\
\hline \multicolumn{7}{|c|}{ Temperate coniferous forests } \\
\hline Aberfeldy ${ }^{\mathrm{b}}$ & 1924 & 597 & 289 & 307 & 6.27 & 1.95 \\
\hline WeidenBrunnen $^{\mathrm{b}}$ & 1319 & -9 & 146 & 164 & 8.04 & -0.06 \\
\hline Tharandt ${ }^{\mathrm{b}}$ & 1806 & 628 & 257 & 266 & 6.79 & 2.36 \\
\hline Loobos $^{\mathrm{b}}$ & 1394 & 254 & 212 & 213 & 6.54 & 1.19 \\
\hline Brasschaat $^{\mathrm{b}}$ & 992 & -146 & 136 & 173 & 5.74 & -0.84 \\
\hline Wind River ${ }^{\mathrm{c}}$ & NA & 327 & NA & 365 & NA & 0.90 \\
\hline Metolius $^{c}$ & 1570 & 273 & 292 & 365 & 4.30 & 0.75 \\
\hline Duke Forest ${ }^{\mathrm{c}}$ & 1487 & 595 & 318 & 339 & 4.39 & 1.75 \\
\hline \multicolumn{7}{|c|}{ High altitude coniferous forests } \\
\hline Niwot Ridge ${ }^{c}$ & 831 & 71 & 180 & 189 & 4.40 & 0.38 \\
\hline \multicolumn{7}{|c|}{ Boreal coniferous forests } \\
\hline North Boreas ${ }^{c}$ & 812 & 6 & 142 & 164 & 4.95 & 0.04 \\
\hline Flakaliden $^{\mathrm{b}}$ & 723 & 115 & 135 & 167 & 4.33 & 0.69 \\
\hline Norunda ${ }^{b}$ & 1691 & -11 & 144 & 142 & 11.91 & -0.08 \\
\hline Hyytiala $^{\mathrm{b}}$ & 959 & 246 & 173 & 182 & 5.27 & 1.35 \\
\hline Howland ${ }^{c}$ & 909 & 251 & 195 & 232 & 3.92 & 1.08 \\
\hline
\end{tabular}


Table 3 (Continued)

\begin{tabular}{|c|c|c|c|c|c|c|}
\hline Site & $\begin{array}{l}F_{\mathrm{GPP}}\left(\mathrm{g} \mathrm{C} \mathrm{m}^{-2}\right. \\
\text { per year) }\end{array}$ & $\begin{array}{l}F_{\mathrm{NEP}}\left(\mathrm{g} \mathrm{C} \mathrm{m}^{-2}\right. \\
\text { per year })\end{array}$ & $\begin{array}{l}S_{\mathrm{GPP} / \mathrm{RE}} \\
\text { (days) }\end{array}$ & $\begin{array}{l}S_{\mathrm{NEP}} \\
\text { (days) }\end{array}$ & $\begin{array}{l}F_{\mathrm{GPP}}^{\mathrm{d}}\left(\mathrm{g} \mathrm{C} \mathrm{m}^{-2}\right. \\
\text { per day })\end{array}$ & $\begin{array}{l}F_{\mathrm{NEP}}^{\mathrm{d}}\left(\mathrm{g} \mathrm{C} \mathrm{m}^{-2}\right. \\
\text { per day })\end{array}$ \\
\hline \multicolumn{7}{|c|}{ Temperate deciduous forests } \\
\hline Vielsalm ${ }^{\mathrm{b}}$ & 1507 & 435 & 218 & 261 & 5.77 & 1.67 \\
\hline Soroe $^{\mathrm{b}}$ & 1276 & 91 & 139 & 141 & 9.05 & 0.64 \\
\hline Hesse $^{\mathrm{b}}$ & 1258 & 129 & 146 & 148 & 8.50 & 0.87 \\
\hline WalkerBranch $^{\mathrm{c}}$ & 1473 & 757 & 216 & 197 & 7.48 & 3.84 \\
\hline Harvard $^{c}$ & 1122 & 181 & 142 & 138 & 8.13 & 1.31 \\
\hline \multicolumn{7}{|c|}{ Cold temperate deciduous forests } \\
\hline Willow Creek ${ }^{\mathrm{c}}$ & 1165 & 313 & 134 & 138 & 8.44 & 2.26 \\
\hline Park Falls/WLEF ${ }^{c}$ & 903 & -22 & 109 & 136 & 6.64 & -0.16 \\
\hline \multicolumn{7}{|c|}{ Boreal deciduous forests } \\
\hline Gunnarsholt ${ }^{\mathrm{b}}$ & NA & NA & NA & 108 & NA & NA \\
\hline \multicolumn{7}{|c|}{ Maritime/Mediterranean evergreen forests } \\
\hline Bordeaux ${ }^{b}$ & 1681 & 454 & 255 & 300 & 5.60 & 1.51 \\
\hline Castelporziano $^{\mathrm{b}}$ & 1683 & 585 & 325 & 324 & 5.19 & 1.81 \\
\hline Sky Oaks young ${ }^{\mathrm{c}}$ & 387 & 60 & 174 & 183 & 2.11 & 0.33 \\
\hline Sky Oaks old ${ }^{\mathrm{c}}$ & 734 & 67 & 144 & 168 & 4.37 & 0.40 \\
\hline Blodgett Forest ${ }^{\mathrm{c}}$ & 1386 & 339 & 256 & 272 & 5.10 & 1.24 \\
\hline \multicolumn{7}{|l|}{ Rainforest } \\
\hline Manaus $^{\mathrm{c}}$ & 3249 & 608 & 365 & 365 & 8.90 & 1.66 \\
\hline \multicolumn{7}{|l|}{ Grasslands } \\
\hline LittleWashita $^{\mathrm{c}}$ & 542 & -212 & 65 & 86 & 6.30 & -2.46 \\
\hline Shidler ${ }^{\mathrm{c}}$ & 1715 & 362 & 154 & 160 & 10.72 & 2.26 \\
\hline Risoe $^{b}$ & NA & 538 & NA & 253 & NA & 2.13 \\
\hline \multicolumn{7}{|l|}{ Crops } \\
\hline Bondville $\mathrm{C}^{\mathrm{c}}$ & 1471 & 588 & 140 & 188 & 7.82 & 3.13 \\
\hline Bondville $^{\mathrm{c}} \mathrm{C} 3$ & 599 & -115 & 85 & 90 & 6.66 & -1.27 \\
\hline Ponca $^{\mathrm{c}}$ & 1396 & 155 & 176 & 211 & 6.62 & 0.74 \\
\hline Soroe $^{\mathrm{b}}$ & 1101 & 303 & 163 & 146 & 7.54 & 2.08 \\
\hline
\end{tabular}

${ }^{\text {a }}$ EUROFLUX projects.

b The $F_{\mathrm{NEP}}$ based season length $\left(S_{\mathrm{NEP}}\right)$ is number of days between spring and fall sign change of $F_{\mathrm{NEP}}$ (for crops uptake-period of inter-crops is included). $S_{\mathrm{GPP} / \mathrm{RE}}$ is the length of the period, where $z=F_{\mathrm{GPP}} / F_{\mathrm{RE}}$ was greater than 1 . Values of $F_{\mathrm{GPP}}^{\mathrm{d}}$ and $F_{\mathrm{NEP}}^{\mathrm{d}}$ are calculated based on $S_{\mathrm{NEP}}$. Data are averaged for all available years.

${ }^{\mathrm{c}}$ AmeriFlux projects.

when $F_{\mathrm{RE}}$ is underestimated (e.g., due to problems in nocturnal flux measurements, see below). Generally, values of $F_{\mathrm{GPP}} / F_{\mathrm{RE}}$ as derived from eddy covariance measurements are high in comparison with model estimates of ecosystem metabolism, for example, seven of eight terrestrial biosphere models evaluated by Nemry et al. (1999) assume or calculate annual equilibrium between $F_{\mathrm{RH}}$ and $F_{\mathrm{NPP}}($ or $z=1$ ) for all locations. Values of $z$ above 1 could be symptomatic for eddy covariance measurements, because of known uncertainties, especially concerning night-time fluxes or flux measurements in complex terrain (e.g., Lee,
1998; Baldocchi et al., 2000; Aubinet et al., 2000). But they are supported by other evidence pointing to a large northern hemispheric terrestrial carbon sink (e.g., Tans et al., 1990; Friedlingstein et al., 1995; Keeling et al., 1996b; Fan et al., 1998; Ciais et al., 1999).

In principle, an estimate of the photosynthetically active season could be derived from the numbers of days where $F_{\mathrm{GPP}}$ is larger than 0 . However, the uncertainty of $F_{\mathrm{RE}}$ estimates is relatively large, eventually leading to positive $F_{\mathrm{GPP}}$ during dormant seasons, as $F_{\mathrm{GPP}}$ is calculated as the sum of $F_{\mathrm{NEP}}$ and $F_{\mathrm{RE}}$. Therefore the length of the season was determined by (1) 


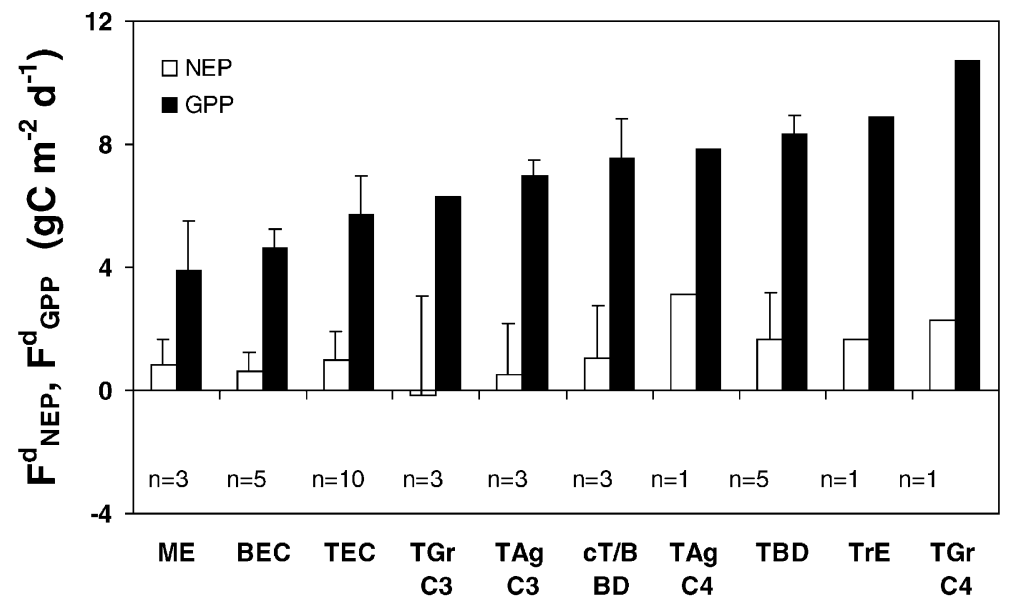

Fig. 9. $F_{\mathrm{GPP}}$ and $F_{\mathrm{NEP}}$ adjusted for length of the carbon uptake period, and averaged for functional vegetation types (ME: Mediterranean evergreen systems; BEC: boreal evergreen conifers; TrE: rainforest; TGr C3: temperate $\mathrm{C}_{3}$ grasslands; TAg C3: temperate $\mathrm{C}_{3}$ crops; TEC: temperate evergreen conifers; TAg $\mathrm{C} 4$ : temperate $\mathrm{C}_{4}$ crops; TBD: temperate broad-leaf deciduous; TGr $\mathrm{C}_{4}$ : temperate $\mathrm{C}_{4}$ grasslands. Vertical bars indicate standard deviation of the mean.

calculating the time span between spring and fall sign change in $F_{\mathrm{NEE}}$, and (2) by counting all days where $F_{\mathrm{GPP}} / F_{\mathrm{RE}}>1$, i.e., $F_{\mathrm{NEP}}$ is positive (Table $3, S_{\mathrm{NEP}}$ and $S_{\mathrm{GPP} / \mathrm{RE}}$, respectively). Annual sums of $F_{\mathrm{GPP}}$ and $F_{\mathrm{NEP}}$ were divided by $S_{\mathrm{NEP}}$ to determine $F_{\mathrm{GPP}}^{\mathrm{d}}$ and $F_{\mathrm{NEP}}^{\mathrm{d}}$, values of $F_{\mathrm{GPP}}$ and $F_{\mathrm{NEP}}$ adjusted for the length of the season. A comparison of these numbers averaged for functional or biome type is given in Fig. 9. Similar values were found for $F_{\mathrm{GPP}}^{\mathrm{d}}$ at the $\mathrm{C}_{4}$ crop systems and temperate and cold temperate/boreal deciduous forest sites (7.8, 8.3 and $7.5 \mathrm{~g} \mathrm{C} \mathrm{m}^{-2}$ per day), for the temperate conifers, $\mathrm{C}_{3}$ crops and $\mathrm{C}_{3}$ grasslands (5.7, 6.9 and $6.3 \mathrm{~g} \mathrm{C} \mathrm{m}^{-2}$ per day, respectively), and the boreal conifers $\left(4.6 \mathrm{~g} \mathrm{C} \mathrm{m}^{-2}\right.$ per day). Values for the Mediterranean systems and a $\mathrm{C}_{4}$ grassland were 3.9 and $10.7 \mathrm{~g} \mathrm{C} \mathrm{m}^{-2}$ perday, the rate at the tropical site was $8.9 \mathrm{~g} \mathrm{C} \mathrm{m}^{-2}$ perday. The patterns observed for $F_{\mathrm{GPP}}^{\mathrm{d}}$ were not reproduced in patterns in $F_{\mathrm{NEP}}^{\mathrm{d}}$ which decreased from 3.1 to $-0.2 \mathrm{~g} \mathrm{C} \mathrm{m}^{-2}$ per day in the order $\mathrm{C}_{4}$ crops $>\mathrm{C}_{4}$ grasslands $>$ temperate deciduous forests, and rainforest $>$ cold temperate/boreal deciduous forests $>$ temperate conifers $>$ Mediterranean systems $>$ boreal conifers $>$ $\mathrm{C}_{3}$ crops $>\mathrm{C}_{3}$ grasslands. The results for the grasslands might be biased due severe drought in one $\mathrm{C}_{3}$ system, and the fact that the $\mathrm{C}$-loss during prescribed burning in the $\mathrm{C}_{4}$ system is not included in the data. In general, $F_{\mathrm{NEP}}^{\mathrm{d}}$ is positive indicating nearly all of the ecosystems in this study represent net sinks for atmospheric $\mathrm{CO}_{2}$. These tower-based estimates need to be confirmed by other methods, for example based on careful allometry. Nevertheless, the overall observed patterns are reasonable, for instance the $\mathrm{C}_{4}$ systems showing higher carbon uptake than the $\mathrm{C}_{3}$ systems, or the relative consistency within the temperate $\mathrm{C}_{3}$ systems (with the exception of temperate deciduous forest sites).

Eddy covariance data do not provide values of $F_{\mathrm{NPP}}$ (net primary productivity $=F_{\mathrm{NEP}}+F_{\mathrm{RH}}$ ), and there are no direct methods to estimate $F_{\mathrm{NPP}}$ from $F_{\mathrm{NEP}}$ or $F_{\mathrm{GPP}}$. Separate measurements of $F_{\mathrm{RH}}$ would be needed. However, $F_{\mathrm{NPP}}$ is the traditional measure of plant productivity in forestry and agriculture and extensive data sets are available. More recently measurements of $F_{\text {NPP }}$ have been used to parameterize and evaluate models of terrestrial carbon cycling to assess the impacts of global land-use and climate change (e.g., Cramer et al., 1999; Jiang et al., 1999; Nemry et al., 1999), and for validation of remote sensing data (Field et al., 1995; Goetz et al., 1999; Running et al., 1999). We used three different sources of $F_{\text {NPP }}$ data of various vegetation types (Lieth, 1975; Schulze, 1982; Waring and Schlesinger, 1985) for comparison with annual $F_{\mathrm{NEP}}$ and $F_{\mathrm{GPP}}$ derived from eddy covariance measurements (Fig. 10). A ratio of 0.45 was used to convert biomass dry weight to carbon content, if 


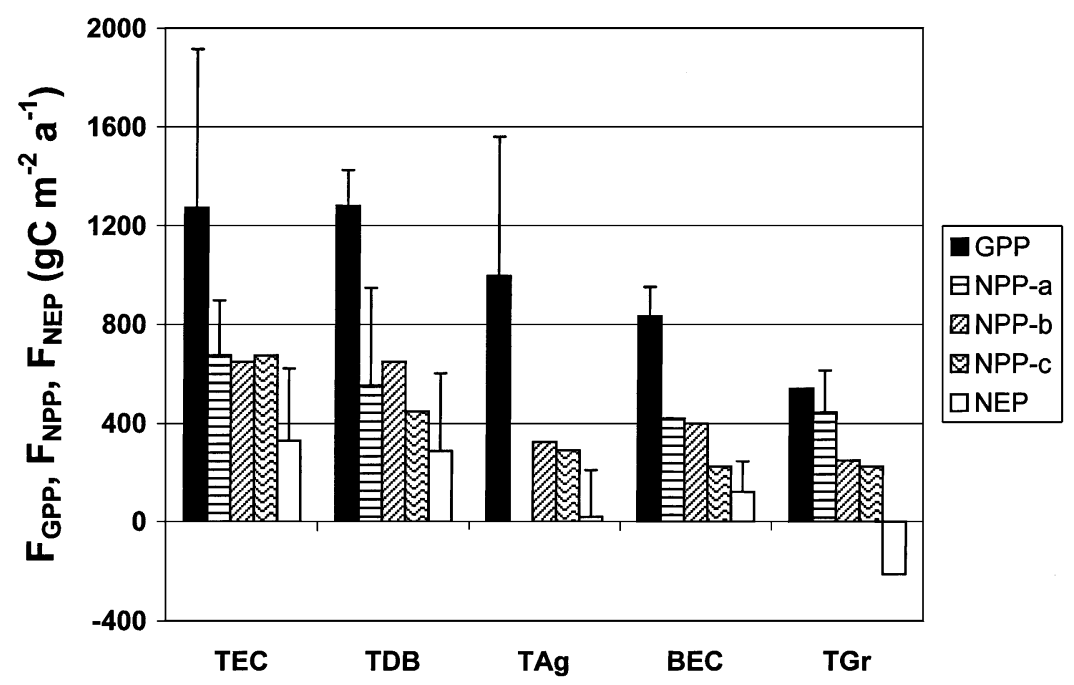

Fig. 10. Average $F_{\mathrm{GPP}}, F_{\mathrm{NPP}}$ and $F_{\mathrm{NEP}}$ for different vegetation types: TEC, temperate evergreen conifers; TDB, temperate deciduous broad-leaf forest; Tag, temperate crops; BEC, boreal evergreen conifers; TGr, temperate grasslands. Vertical bars indicate standard deviation of the mean. $F_{\mathrm{GPP}}$, and $F_{\mathrm{NEP}}$ are derived from the eddy covariance data of this study. The three $F_{\mathrm{NPP}}$ estimates are from (a) Schulze (1982), (b) Waring and Schlesinger (1985), and (c) Lieth (1975).

applicable. For the forest ecosystems annual $F_{\mathrm{GPP}}$, $F_{\mathrm{NPP}}$ and $F_{\mathrm{NEP}}$ all decreased comparing the temperate and boreal zones. However, the decrease in $F_{\mathrm{NEP}}$ is greater than in $F_{\mathrm{NPP}}$ or $F_{\mathrm{GPP}}$. Our results show a strong latitudinal trend in the ratio $F_{\mathrm{NEP}} / F_{\mathrm{GPP}}$ for forest ecosystems: $26 \%$ for the temperate evergreen conifers, $23 \%$ for the temperate deciduous broad-leaf forests, and $15 \%$ for the boreal evergreen conifers. The relative contribution of $F_{\mathrm{NPP}}$ to $F_{\mathrm{GPP}}$ is more constant: $51 \%$ for the temperate evergreen conifers and temperate deciduous broad-leaf forests, and $48 \%$ for the boreal evergreen conifers. These values highlight a similar contribution of autotrophic respiration to ecosystem carbon metabolism in the temperate and the boreal systems (49-52\%). On the other hand, total respiratory costs of assimilated carbon are higher in the boreal systems (85\% for boreal systems compared to $74-77 \%$ for temperate), indicating a larger contribution of $F_{\mathrm{RH}}$ to total ecosystem respiration in boreal systems.

\section{Conclusion}

Using tower-base ecosystem-atmosphere exchange data from the FLUXNET database, we have inves- tigated seasonal patterns of $F_{\mathrm{GPP}}$, and $F_{\mathrm{RE}}$, derived values of $F_{\mathrm{NEE}}$ and $F_{\mathrm{GPP}}$ adjusted for length of the carbon uptake period and compared annual $F_{\mathrm{GPP}}$ with

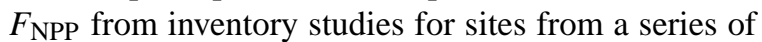
functional vegetation types. The analysis included boreal and temperate, deciduous and coniferous forests, Mediterranean evergreen systems, a rainforest, temperate grasslands, and $\mathrm{C}_{3}$ and $\mathrm{C}_{4}$ crops.

Striking parallels in the seasonal pattern of $F_{\mathrm{GPP}}$ and $F_{\mathrm{RE}}$ were observed within and between the vegetation types, in terms of seasonal amplitude and phasing of net carbon fluxes, and the relative contribution of photosynthesis and respiration. Our results indicate that temperate and boreal conifers should be viewed as separate classes. Generalized seasonal patterns might be utilized by global modelers and in inversion studies, and to validate the phenology modules of plot scale models.

For the temperate deciduous and boreal conifers, we identified periods of unbalanced respiratory and assimilatory processes, indicating a potentially higher susceptibility to changes in management practices or climatic conditions, especially considering the expected larger increase in night-time temperatures globally, and greater temperature increases at high latitudes. 
Table 4

Minimum, maximum, average and standard deviation of regression coefficients $R^{2}$ of 32 sites from the EUROFLUX and AmeriFlux projects

\begin{tabular}{|c|c|c|c|c|c|c|}
\hline \multirow[t]{2}{*}{ Site } & \multirow[t]{2}{*}{ Year } & \multicolumn{4}{|l|}{$R^{2}$} & \multirow[t]{2}{*}{ Periods $(n)$} \\
\hline & & Minimum & Maximum & Average & S.D. & \\
\hline \multicolumn{7}{|c|}{ Temperate coniferous forests } \\
\hline Aberfeldy ${ }^{\mathrm{a}}$ & 1998 & 0.793 & 0.97 & 0.902 & 0.049 & 335 \\
\hline WeidenBrunnen $^{\mathrm{a}}$ & 1998 & 0.539 & 0.969 & 0.871 & 0.105 & 317 \\
\hline Tharandt $^{\mathrm{a}}$ & 1999 & 0.336 & 0.864 & 0.696 & 0.164 & 335 \\
\hline Loobos $^{\mathrm{a}}$ & 1997 & 0.12 & 0.89 & 0.721 & 0.127 & 322 \\
\hline Brasschaat $^{\mathrm{a}}$ & 1998 & 0.22 & 0.845 & 0.683 & 0.14 & 321 \\
\hline Wind River ${ }^{\mathrm{b}}$ & 1998 & 0.12 & 0.615 & 0.373 & 0.16 & 223 \\
\hline Howland $^{\mathrm{b}}$ & 1997 & 0.102 & 0.705 & 0.493 & 0.174 & 335 \\
\hline Duke Forest ${ }^{\mathrm{b}}$ & 1999 & 0.288 & 1 & 0.604 & 0.162 & 305 \\
\hline \multicolumn{7}{|c|}{ High altitude coniferous forests } \\
\hline Niwot Ridge ${ }^{b}$ & 2000 & 0.543 & 0.977 & 0.809 & 0.127 & 335 \\
\hline \multicolumn{7}{|c|}{ Boreal coniferous forests } \\
\hline North Boreas ${ }^{\mathrm{b}}$ & 1995 & 0.162 & 0.926 & 0.682 & 0.239 & 335 \\
\hline Flakaliden $^{\mathrm{a}}$ & 1997 & 0.16 & 0.86 & 0.717 & 0.138 & 330 \\
\hline Norunda $^{\mathrm{a}}$ & 1997 & 0.221 & 0.818 & 0.645 & 0.138 & 335 \\
\hline Hyytiala $^{a}$ & 1998 & 0.206 & 0.975 & 0.751 & 0.248 & 335 \\
\hline \multicolumn{7}{|c|}{ Temperate deciduous forests } \\
\hline Vielsalm ${ }^{\mathrm{a}}$ & 1998 & 0.131 & 0.596 & 0.382 & 0.109 & 335 \\
\hline Soroe $^{\mathrm{a}}$ & 1997 & 0.246 & 0.952 & 0.686 & 0.216 & 335 \\
\hline Hesse $^{\mathrm{a}}$ & 1998 & 0.461 & 0.871 & 0.718 & 0.1 & 335 \\
\hline Harvard $^{\mathrm{b}}$ & 1999 & 0.441 & 0.902 & 0.774 & 0.092 & 335 \\
\hline WalkerBranch $^{\mathrm{b}}$ & 1998 & 0.123 & 0.67 & 0.445 & 0.157 & 335 \\
\hline \multicolumn{7}{|c|}{ Cold temperate deciduous forests } \\
\hline Park Falls/WLEF & 1998 & 0.173 & 0.873 & 0.587 & 0.182 & 335 \\
\hline Willow Creek ${ }^{\mathrm{b}}$ & 2000 & 0.29 & 0.841 & 0.685 & 0.125 & 335 \\
\hline \multicolumn{7}{|c|}{ Boreal deciduous forests } \\
\hline Gunnarsholt ${ }^{\mathrm{a}}$ & 1997 & 0.277 & 0.978 & 0.805 & 0.173 & 263 \\
\hline \multicolumn{7}{|c|}{ Maritime/Mediterranean evergreen forests } \\
\hline Bordeaux $^{\mathrm{a}}$ & 1998 & 0.885 & 0.992 & 0.947 & 0.03 & 181 \\
\hline Castelporziano $^{\mathrm{a}}$ & 1997 & 0.614 & 0.773 & 0.704 & 0.032 & 335 \\
\hline Sky Oaks young b & 1998 & 0.607 & 0.999 & 0.832 & 0.092 & 207 \\
\hline Sky Oaks old b & 1998 & 0.91 & 1 & 0.966 & 0.023 & 101 \\
\hline Blodgett Forest ${ }^{\mathrm{b}}$ & 2000 & 0.642 & 0.999 & 0.85 & 0.066 & 152 \\
\hline \multicolumn{7}{|l|}{ Grasslands } \\
\hline LittleWashita $^{\mathrm{b}}$ & 1998 & 0.053 & 0.897 & 0.6 & 0.224 & 289 \\
\hline Shidler ${ }^{\mathrm{b}}$ & 1997 & 0.306 & 0.973 & 0.824 & 0.2 & 335 \\
\hline \multicolumn{7}{|l|}{ Crops } \\
\hline Bondville ${ }^{\mathrm{b}}$ & 2000 & 0.051 & 0.964 & 0.574 & 0.288 & 332 \\
\hline Bondville $^{\mathrm{b}}$ & 1997 & 0.057 & 0.874 & 0.49 & 0.291 & 305 \\
\hline Ponca $^{\mathrm{b}}$ & 1997 & 0.781 & 0.979 & 0.894 & 0.042 & 229 \\
\hline Soroe $^{\mathrm{a}}$ & 1999 & 0.101 & 0.761 & 0.466 & 0.147 & 280 \\
\hline
\end{tabular}

\footnotetext{
${ }^{a}$ EUROFLUX projects.
}

b AmeriFlux projects. 
Overall, most of the sites we investigated sequester carbon, supporting the widely reported northern hemispheric terrestrial biosphere sink.

Our observation that $F_{\mathrm{GPP}}^{\mathrm{d}}$, adjusted for the length of the season, is not constant over various functional vegetation types and has important validation potential for global carbon cycle modeling. For the sites in this study, values of $F_{\mathrm{GPP}}^{\mathrm{d}}$ decreased from 10.7 to $2.4 \mathrm{~g} \mathrm{C} \mathrm{m}^{-2}$ perday in the order $\mathrm{C}_{4}$ grassland $>$ rainforest $>\mathrm{C}_{4}$ crops and temperate deciduous forests $>\mathrm{C}_{3}$ crops, grassland and temperate conifers $>$ boreal conifers $>$ Mediterranean systems.

To investigate the impacts of global land-use and climate change, models of terrestrial carbon cycling and validation approaches of remote sensing data primarily assess $F_{\mathrm{NPP}}$. Comparing $F_{\mathrm{NPP}}$ from various literature sources with annual values of $F_{\mathrm{NEP}}$ and $F_{\mathrm{GPP}}$ well-known latitudinal gradients were confirmed, and the relative contribution of $F_{\mathrm{RH}}$ to the total respiratory costs of assimilation of various vegetation types was estimated. However, our ability to compare our results directly to on-site estimates of $F_{\mathrm{NPP}}$ is constrained by the lack of sites where both long-term eddy covariance data and measurements of net primary productivity are available. To overcome these limitations future investigations at tower sites should preferably be complemented by inventory studies of carbon stock changes.

\section{Acknowledgements}

This work is supported by the BMBF project BITÖK (PT BEO 51-0339476) and the FLUXNET program (sponsored by NASA's EOS Validation Program). It contributes to the projects CARBODATA and CARBOEUROFLUX of the European Union (supported by the EC's Fifth Framework Program, R\&TD contract CARBOEUROFLUX, contract no. EVK2-CT-1999-0032), and the AmeriFlux program (US Department of Energy's Terrestrial Carbon Program, and NIGEC Program).

\section{Appendix A}

Estimates of $F_{\mathrm{GPP}}$ depend crucially on the quality of derived $F_{\mathrm{RE}}$ values, as $F_{\mathrm{GPP}}$ is calculated as the sum of $F_{\mathrm{RE}}$ and measured $F_{\mathrm{NEP}}$. Apparently, the derivation of $F_{\mathrm{RE}}$ and the quality of the fit of Eq. (1) to night-time fluxes of $F_{\mathrm{NEP}}$ is critical to all the results and conclusions presented in this paper. During data processing ca. 36,000 of such fits were performed, 335 fits for each of 103 site-years (335 running periods of 30-days; for more information, see Section 2). For illustration, Table 4 lists minimum, maximum, average and standard deviation (S.D.) of the $335 R^{2}$-values of one-third of the available site-years. Comparing the average $R^{2}$ and S.D. of all 103 site-years reveals that maritime/Mediterranean systems and coniferous forests show the largest average $\left(R^{2}=0.73\right.$ and 0.72$)$. Deciduous forests and grasslands have intermediate values of average $R^{2}=0.65$ and 0.70 , respectively. Lowest average $R^{2}$ of 0.61 are found for the cropland sites, indicating that the confidence in derived $F_{\mathrm{RE}}$ values decreases in the order evergreen forest $>$ deciduous forest $>$ grassland $>$ crop sites. In addition, the seasonal variation in $R^{2}$ increases in more or less the same order, indicated by the average standard deviation of $F_{\mathrm{RE}}$ values within those groups, 0.08 for the maritime/Mediterranean sites, 0.14 for coniferous forest sites, 0.15 for deciduous forest sites, 0.23 for grasslands, and 0.22 for crops. Especially for the latter the seasonal values of $R^{2}$ were quite variable: periods where $R^{2}$ dropped below 0.2 coincided, e.g. with non-vegetated periods for crops, or temperatures below freezing. Yet during those periods overall respiration rates are expected to be quite low, so that eventual errors due to the low quality of the fit are small, and we decided to keep the respective $F_{\mathrm{RE}}$ estimates to calculate monthly and annual sums of $F_{\mathrm{RE}}$ and $F_{\mathrm{GPP}}$.

\section{References}

Alward, R.D., Detling, J.K., Milchunas, D.G., 1999. Grassland vegetation changes and nocturnal global warming. Science 283 , 229-231.

Amiro, B.D., 2001. Paired-tower measurements of carbon and energy fluxes following disturbance in the boreal forest. Global Change Biol. 7, 253-268.

Aubinet, M., Grelle, A., Ibrom, A., Rannik, Ü., Moncrieff, J., Foken, T., Kowalski, A.S., Martin, P.H., Berbigier, P., Bernhofer, Ch., Clement, R., Elbers, J., Granier, A., Grünwald, T., Morgenstern, K., Pilegaard, K., Rebmann, C., Snijders, W., Valentini, R., Vesala, T., 2000. Estimates of the annual net carbon and water exchange of forests: the EUROFLUX methodology. Adv. Ecol. Res. 30, 113-175.

Baldocchi, D.D., Finnigan, J., Wilson, K., Paw U, K.T., Falge, E., 2000. On measuring net ecosystem carbon exchange over tall 
vegetation on complex terrain. Boundary Layer Meteorol. 96, 257-291.

Baldocchi, D., Falge, E., Wilson, K., 2001. A spectral analysis of biosphere-atmosphere trace gas flux densities and meteorological variables across hour to multi-year time scales. Agric. For. Meteorol. 107, 1-27.

Bergen, K., Dobson, M.C., 1999. Integration of remotely sensed radar imagery in modeling and mapping of forest biomass and net primary production. Ecol. Modell. 122, 257-274.

Black, T.A., den Hartog, G., Neumann, H.H., Blanken, P.D., Yang, P.C., Russell, C., Nesic, Z., Lee, X., Chen, S.G., Staebler, R., Novak, M.D., 1996. Annual cycles of water vapour and carbon dioxide fluxes in and above a boreal aspen forest. Global Change Biol. 2, 101-111.

Black, T.A., Chen, W.J., Barr, A.G., Arain, M.A., Chen, Z., Nesic, Z., Hogg, E.H., Neumann, H.H., Yang, P.C., 2000. Increased carbon sequestration by a boreal deciduous forest in years with a warm spring. Geophys. Res. Lett. 27, 1271-1274.

Ciais, P., Friedlingstein, P., Schimel, D.S., Tans, P.P., 1999. A global calculation of the delta $\mathrm{C}-13$ of soil respired carbon: implications for the biospheric uptake of anthropogenic $\mathrm{CO}_{2}$. Global Biogeochem. Cy. 13 (2), 519-530.

Cramer, W., Kicklighter, D.W., Bondeau, A., Moore, III, B., Churkina, G., Nemry, B., Ruimy, A., Schloss, A.L., The Participants of the Potsdam NPP Model Intercomparison, 1999. Comparing global models of terrestrial net primary productivity (NPP): overview and key results. Global Change Biol. 5 (Suppl.), 1-15.

Davidson, E.A., Belk, E., Boone, R.D., 1998. Soil water content and temperature as independent or confounded factors controlling soil respiration in a temperate mixed hardwood forest. Global Change Biol. 4, 217-227.

Easterling, D.R., Horton, B., Jones, P.D., Peterson, T.C., Karl, T.R., Parker, D.E., Salinger, M.J., Razuvayev, V., Plummer, N., Jamason, P., Folland, C.K., 1997. Maximum and minimum temperature trends for the globe. Science 277, 364-367.

Edwards, N.T., 1975. Effects of temperature and moisture on carbon dioxide evolution in a mixed deciduous forest floor. Soil Sci. Soc. Am. Proc. 39, 361-365.

Falge, E., Baldocchi, D., Olson, R.J., Anthoni, P., Aubinet, M., Bernhofer, C., Burba, G., Ceulemans, R., Clement, R., Dolman, H., Granier, A., Gross, P., Grünwald, T., Hollinger, D., Jensen, N.-O., Katul, G., Keronen, P., Kowalski, A., Ta Lai, C., Law, B.E., Meyers, T., Moncrieff, J., Moors, E., Munger, J.W., Pilegaard, K., Rannik, Ü., Rebmann, C., Suyker, A., Tenhunen, J., Tu, K., Verma, S., Vesala, T., Wilson, K., Wofsy, S., 2001. Gap filling strategies for defensible annual sums of net ecosystem exchange. Agric. Meteorol. 107, 43-69.

Falge, E., Tenhunen, J.D., Baldocchi, D.D., Aubinet, M., Bakwin, P., Berbigier, P., Bernhofer, C., Bonnefond, J.-M., Burba, G., Clement, R., Davis, K.J., Elbers, J.A., Falk, M., Goldstein, A.H., Grelle, A., Granier, A., Grünwald, T., Guð̈mundsson, J., Hollinger, D., Janssens, I.A., Keronen, P., Kowalski, A.S., Katul, G., Law, B.E., Malhi, Y., Meyers, T., Monson, R.K., Moors, E., Munger, J.W., Oechel, W., Paw U, K.T., Pilegaard, K., Rannik, U., Rebmann, C., Suyker, A., Thorgeirsson, H., Tirone, G., Turnipseed, A., Wilson, K., Wofsy, S., 2002. Phase and amplitude of ecosystem carbon release and uptake potentials as derived from FLUXNET measurements. Agric. For. Meteorol. 113, 75-95.

Fan, S., Gloor, M., Mahlman, J., Pacala, S., Sarmiento, J., Takahashi, T., Tans, P., 1998. A large terrestrial carbon sink in North America implied by atmospheric and oceanic carbon dioxide data and models. Science 282, 442-446.

Field, C.B., Randerson, J.T., Malmström, C.M., 1995. Global net primary production: combining ecology and remote sensing. Remote Sens. Environ. 51, 74-88.

Field, C.B., Behrenfeld, M.J., Randerson, J.T., Falkowski, P., 1998. Primary production of the biosphere: integrating terrestrial and oceanic components. Science 281, 237-240.

Fliebach, A., Sarig, S., Steinberger, Y., 1994. Effects of water pulses and climatic conditions on microbial biomass kinetics and microbial activity in a Yermosol of the central Negev. Arid Soil Res. Rehab. 8, 353-362.

Friedlingstein, P., Fung, I., Holland, E., John, J., Brasseur, G., Erickson, D., Schimel, D., 1995. On the contribution of $\mathrm{CO}_{2}$ fertilization to the missing biospheric sink. Global Biogeochem. Cy. 9 (4), 541-556.

Goetz, S.J., Prince, S.D., Goward, S.N., Thawley, M.M., Small, J., 1999. Satellite remote sensing of primary production: an improved production efficiency modeling approach. Ecol. Modell. 122, 239-255.

Goulden, M.L., Munger, J.W., Fan, S.M., Daube, B.C., Wofsy, S.C., 1996. Measurement of carbon storage by long-term eddy correlation: methods and a critical assessment of accuracy. Global Change Biol. 2, 169-182.

Goulden, M.L., Wofsy, S.C., Harden, J.W., Trumbore, S.E., Crill, P.M., Gower, S.T., Fries, T., Daube, B.C., Fan, S.M., Sutton, D.J., Bazzaz, A., Munger, J.W., 1998. Sensitivity of boreal forest carbon balance to soil thaw. Science 279, 214-217.

Hanson, P.J., Wullschleger, S.D., Bohlman, S.A., Todd, D.E., 1993. Seasonal and topographic patterns of forest floor $\mathrm{CO}_{2}$ efflux from an upland oak forest. Tree Physiol. 13, 1-15.

Hasenauer, H., Nemani, R.R., Schadauer, K., Running, S.W., 1999. Forest growth response to changing climate between 1961 and 1990 in Austria. For. Ecol. Manage. 122, 209-219.

Houghton, J.T., Meira Filho, L.G., Callander, B.A., Harris, N., Kattenberg, A., Maskell, K. (Eds.), 1996. Climate Change 1995-The Science of Climate Change. Cambridge University Press, Cambridge.

Jackson, R.B., Lechowicz, M.J., Li, X., Mooney, H.A., 2000. The roles of phenology, growth, and allocation in global terrestrial productivity. In: Mooney, H.A., Saugier, B., Roy, J. (Eds.), Terrestrial Global Productivity: Past, Present, and Future. Academic Press, San Diego, pp. 61-82.

Janssen, I.A., Lankreijer, H., Matteucci, G., Kowalski, A.S., Buchmann, N., Epron, D., Pilegaard, K., Kutsch, W., Longdoz, B., Grünwald, T., Montagnani, L., Dore, S., Rebmann, C., Moors, E.J., Grelle, A., Rannik, Ü., Morgenstern, K., Oltchev, S., Clement, R., Guð̋mundsson, J., Minerbi, S., Berbigier, P., Ibrom, A., Moncrieff, J., Aubinet, M., Bernhofer, C., Jensen, N.-O., Vesala, T., Granier, A., Schulze, E.-D., Lindroth, A., Dolman, A.J., Jarvis, P.G., Ceulemans, R., Valentini, R., 2001. Productivity overshadows temperature in determining soil and 
ecosystem respiration across European forests. Global Change Biol. 7, 269-278.

Jiang, H., Apps, M.J., Zhang, Y., Peng, Ch., Woodward, P.M., 1999. Modelling the spatial pattern of net primary productivity in Chinese forests. Ecol. Modell. 122, 275-288.

Keeling, C.D., Chin, J.F.S., Whorf, T.P., 1996a. Increased activity of northern vegetation inferred from atmospheric $\mathrm{CO}_{2}$ observations. Nature 382, 146-149.

Keeling, R.F., Piper, S.C., Heimann, M., 1996b. Global and hemispheric $\mathrm{CO}_{2}$ sinks deduced from changes in atmospheric $\mathrm{O}_{2}$ concentration. Nature 381, 218-221.

Keyser, A.R., Kimball, J.S., Nemani, R.R., Running, S.W., 2000. Simulating the effects of climate change in the carbon balance of North American high-latitude forests. Global Change Biol. 6, 185-195.

Kohlmaier, G.H., Badeck, F.-W., Otto, R.D., Häger, C., Dönges, S., Kindermann, J., Würth, G., Lang, T., Jäkel, U., Nadler, A., Ramge, P., Klaudius, A., Habermehl, S., Lüdeke, M.K.B., 1997. The Frankfurt Biosphere Model: a global process-oriented model for the seasonal and long-term $\mathrm{CO}_{2}$ exchange between terrestrial ecosystems and the atmosphere. II. Global results for potential vegetation in an assumed equilibrium state. Climate Res. 8, 61-87.

Law, B.E., Ryan, M.G., Anthoni, P.M., 1999. Seasonal and annual respiration of a Ponderosa pine ecosystem. Global Change Biol. 5 (1), 69-182.

Law, B., Williams, M., Anthoni, P., Baldocchi, D.D., Unsworth, M.H., 2000. Measuring and modeling seasonal variation of carbon dioxide and water vapor exchange of a Pinus ponderosa forest subject to soil water deficit. Global Change Biol. 6, 613-630.

Lee, X., 1998. On micrometeorological observations of surface-air exchange over tall vegetation. Agric. Meteorol. 91, 39-50.

Lieth, H.F.H., 1975. Primary production of the major vegetation units of the world. In: Lieth, H., Whittaker, R.H. (Eds.), Primary Productivity of the Biosphere: Ecological Studies, Vol. 14. Springer, Berlin, pp. 203-215.

Lloyd, J., Taylor, J.A., 1994. On the temperature dependence of soil respiration. Funct. Ecol. 8, 315-323.

Menzel, A., Fabian, P., 1999. Growing season extended in Europe. Nature 397, 659.

Meyers, T., 2001. A comparison of summertime water and $\mathrm{CO}_{2}$ fluxes over rangeland for well watered and drought conditions, Agric. Meteorol. 106, 205-214.

Moncrieff, J.B., Mahli, Y., Leuning, R., 1996. The propagation of errors in long term measurements of land atmosphere fluxes of carbon and water. Global Change Biol. 2, 231-240.

Myneni, R.B., Keeling, C.D., Tucker, C.J., Asrar, G., Nemani, R.R., 1997. Increased plant growth in the northern high latitudes from 1981 to 1991. Nature 386, 698-702.

Nemry, B., François, L., Gérard, J.-C., Bondeau, A., Heimann, M., The Participants of the Potsdam NPP model intercomparison, 1999. Comparing global models of terrestrial net primary productivity (NPP): analysis of the seasonal atmospheric $\mathrm{CO}_{2}$ signal. Global Change Biol. 5 (Suppl.), 65-76.

Raich, J.W., Schlesinger, W.H., 1992. The global carbon dioxide flux in soil respiration and its relationship to vegetation and climate. Tellus B 44, 81-99.
Raich, J.W., Tufekciogul, A., 2000. Vegetation and soil respiration: correlations and controls. Biogeochemistry 48 (1), 71-90.

Randerson, J.T., Field, C.B., Fung, I.Y., Tans, P.P., 1999. Increases in early season ecosystem uptake explain recent changes in the seasonal cycle of atmospheric $\mathrm{CO}_{2}$ at high northern latitudes. Geophys. Res. Lett. 26, 2765-2768.

Rastetter, E.B., McKane, R.B., Shaver, G.R., Melillo, J.M., 1992. Changes in $\mathrm{C}$ storage by terrestrial ecosystems: how $\mathrm{C}-\mathrm{N}$ interactions restrict responses to $\mathrm{CO}_{2}$ and temperature. Water Air Soil Poll. 64, 327-344.

Running, S.W., Baldocchi, D.D., Turner, D., Gower, S.T., Bakwin, P., Hibbard, K., 1999. A global terrestrial monitoring network, scaling tower fluxes with ecosystem modeling and EOS satellite data. Remote Sens. Environ. 70, 108-127.

Schulze, E.-D., 1982. Plant life forms as related to plant carbon, water and nutrient relations. In: Lange, O.L., Nobel, P.S., Osmond, C.B., Ziegler, H. (Eds.), Encyclopedia of Plant Physiology, Physiological Plant Ecology, Water Relations and Photosynthetic Productivity, Vol. 12B. Springer, Berlin, pp. 615-676.

Schulze, E.-D., Lloyd, J., Kelliher, F.M., Wirth, C., Rebmann, C., Luhker, B., Mund, M., Knohl, A., Milyukova, I.M., Schulze, W., Ziegler, W., Varlagin, A.B., Sogachev, A.F., Valentini, R., Dore, S., Grigoriev, S., Kolle, O., Panfyorov, M.I., Tchebakova, N., Vygodskaya, N.N., 1999. Productivity of forests in the Eurosiberian boreal region and their potential to act as a carbon sink - a synthesis. Global Change Biol. 5 (6), 703-722.

Sellers, P.J., Randall, D.A., Collatz, G.J., Berry, J.A., Field, C.B., Dazlich, D.A., Zhang, C., Collelo, G.D., Bounoua, L., 1996a. A revised land surface parameterization $\left(\mathrm{SiB}_{2}\right)$ for atmospheric GCMs. Part I. Model formulation. J. Climatol. 9, 676-705.

Sellers, P.J., Los, S.O., Tucker, C.J., Justice, C.O., Dazlich, D.A., Collatz, G.J., Randall, D.A., 1996b. A revised land surface parameterization $\left(\mathrm{SiB}_{2}\right)$ for atmospheric GCMs. Part II. The generation of global fields of terrestrial biophysical parameters from satellite data. J. Climatol. 9, 706-737.

Suyker, A.E., Verma, Sh.B., 2001. Year-round observations of the net ecosystem exchange of carbon dioxide in a native tall grass prairie. Global Change Biol. 7, 279-289.

Tans, P.P., Fung, I.Y., Takahashi, T., 1990. Observational constraints on the global atmospheric $\mathrm{CO}_{2}$ budget. Science 247, 1431-1438.

Valentini, R. (Ed.), 2002. Fluxes of Carbon, Water and Energy of European Forests, Ecological Studies Series, Springer Verlag, Heidelberg, (in press).

Valentini, R., Matteucci, G., Dolman, A.J., Schulze, E.-D., Rebmann, C., Moors, E.J., Granier, A., Gross, P., Jensen, N.-O., Pilegaard, K., Lindroth, A., Grelle, A., Bernhofer, C., Grünwald, T., Aubinet, M., Ceulemans, R., Kowalski, A.S., Vesala, T., Rannik, U., Berbigier, P., Loustau, D., Guð̋mundsson, J., Thorgeirsson, H., Ibrom, A., Morgenstern, K., Clement, R., Moncrieff, J., Montagnani, L., Minerbi, S., Jarvis, P., 2000. Respiration as the main determinant of carbon balance in European forests. Nature 404, 861-865.

Walker, B.H., Steffen, W.L., Langridge, J., 1999. Interactive and integrated effects of global change on terrestrial ecosystems. In: Walker, B.H., Steffen, W.L., Canadell, J., Ingram, J.S.I. 
(Eds.), Implications of Global Change for Natural and Managed Ecosystems: A Synthesis of GCTE and Related Research. International Geosphere-Biosphere Programme (IGBP) Book Series No. 4, Cambridge University Press, Cambridge, UK.

Waring, R.H., Schlesinger, W.H., 1985. Forest Ecosystems: Concepts and Management. Academic Press, San Diego, CA, pp. 263-276.

Warnant, P., Francois, L., Strivay, D., Gerard, J.-C., 1994. CARAIB: a global model of terrestrial biological productivity. Global Biogeochem. Cy. 8, 255-270.
White, M.A., Running, S.W., Thornton, P.E., 1999. The impact of growing-season length variability on carbon assimilation and evapotranspiration over 88 years in the eastern US deciduous forest. Int. J. Biometeorol. 42, 139-145.

$\mathrm{Xu}, \mathrm{M} ., \mathrm{Qi}, \mathrm{Y}$., 2001. Soil surface $\mathrm{CO}_{2}$ efflux and its spatial and temporal variations in a young Ponderosa pine plantation in northern California. Global Change Biol. 7, 667-677.

Xu, M., DeBiase, T., Qi, Y., Goldstein, A., Liu, Z., 2001. Ecosystem respiration in a young Ponderosa pine plantation in the Sierra Nevada Mountains, California. Tree Physiol. 21, 309-318. 